\section{PATTERNS OF ICE-RAFTED DETRITUS IN THE GLACIAL NORTH ATLANTIC $\left(40-55^{\circ} \mathrm{N}\right)$}

\author{
F. E. Grousset, 1,2 L. Labeyrie, ${ }^{3}$ J. A. Sinko, ${ }^{1}$ M. \\ Cremer, ${ }^{1}$ G. Bond, ${ }^{2}$ J. Duprat, ${ }^{1}$ E. Cortijo, ${ }^{3}$ S. \\ Huon 4
}

\begin{abstract}
The observation by Heinrich (1988) that, during the last glacial period, much of the input of ice-rafted detritus to the North Atlantic sediments may have occurred as a succession of catastrophic events, rekindled interest on the history of the northern ice sheets over the last glacial period. In this paper, we present a rapid method to study the distribution of these events (both in space and time) using whole core low-field magnetic susceptibility. We report on approximately 20 cores covering the last 150 to $250 \mathrm{kyr}$. Well-defined patterns of icerafted detritus appear during periods of large continental ice-sheet extent, although these are not always associated within their maxima. Most of the events may be traced across the North Atlantic Ocean. For the six most recent Heinrich layers (HL), two distinct patterns exist: HL1, HL2, HL4, HL5 are distributed along the northern boundary of the Glacial Polar
\end{abstract}

\footnotetext{
${ }^{1}$ Département de Géologie et Océanographie, Université Bordeaux I, Talence, France.

${ }^{2}$ Lamont-Doherty Earth Observatory, Columbia University, Palisades.

${ }^{3}$ Centre des Faibles Radioactivités, Gif-surYvette, France.

4Département de Minéralogie, Genève, Switzerland.
}

Copyright 1993

by the American Geophysical Union.

Paper number 92PA02923.

0883-8305/93/92PA-02923\$10.00
Front, over most of the North Atlantic between $\approx 40^{\circ}$ and $50^{\circ} \mathrm{N}$; HL3 is more restricted to the central and eastern part of the northern Atlantic. The $\mathrm{Nd}-\mathrm{Sr}$ isotopic composition of the material constituting different Heinrich events indicates the different provenance of the two patterns: HL3 has a typical Scandinavia-Arctic-Icelandic "young crust" signature, and the others have a large component of northern Quebec and northern West Greenland "old crust" material. These isotopic results, obtained on core SU-9008 from the North American basin, are in agreement with the study by Jantschik and Huon (1992), who used K-Ar dating of silt- and clay-size fractions of an eastern basin core (ME-68-89). These data confirm the large spatial scale of these events, and the enormous amount of ice-rafted detritus they represent.

\section{INTRODUCTION}

Ruddiman [1977] demonstrated that the last glacial period was characterized by a large increase in the input of ice-rafted detritus to the North Atlantic Ocean, with a preferential accumulation north of the location of the glacial polar front $\left(40^{\circ}-55^{\circ} \mathrm{N}\right)$. His work indicated a first-order dependence of the icerafted detritus fluxes in the North Atlantic on the volume of the continental ice sheets.

By studying cores from the Northeast Atlantic Basin $\left(\approx 47^{\circ} \mathrm{N}-20^{\circ} \mathrm{W}\right)$ at high resolution (one sample each $\approx 3 \mathrm{~cm}$ ), Heinrich [1988] has demonstrated that a series of six sharp events of ice-rafted detritus occurred roughly every $\approx 11 \mathrm{kyr}$, during the last glacial period. Broecker et al. [1992] reported similar results in the uppermost meters of Ocean Drilling Program (ODP) site $609\left(50^{\circ} \mathrm{N}, 24^{\circ} \mathrm{W}\right)$. Thus the 
"Heinrich layers" (HL) are not a local feature and occur throughout the northern North Atlantic Ocean. Broecker et al. [1992] and Bond et al. [1992] have demonstrated that these events are associated with a drastic reduction in the flux of foraminifera shells, and a shift toward monospecific $N$. pachyderma (sinistral) populations and deposition of sediment rich in detrital carbonate, probably derived from eastern Canada. The input of ice-rafted detritus is associated with major cooling of the northern North Atlantic Ocean [Bond et al., 1992]. These results raise questions on the stability of glacial ice sheets. Heinrich [1988] raised the possibility of preferential transport of ice rafted detritus to the south, at periods of maximum extent of the ice sheet. Broecker et al. [1992] and Bond et al. [1992] also hypothesized that the northern ice sheets could be affected by large pseudoperiodic surges. Further understanding of the nature of these events, their spatial and temporal distributions, and their origin(s), is necessary. We present here a set of observations relevant to this question, mainly based on records of the low-field magnetic susceptibility made in 18 cores distributed over the northern North Atlantic.

\section{DISTRIBUTION OF THE "HEINRICH LAYERS"}

The discovery of the so-called "Heinrich layers" is attributable to the increased resolution of downcore sediment studies: their thickness is commonly less than $10 \mathrm{~cm}$, and they typically occur several tens of centimeters apart. High-resolution results were attained by Bond et al. [1991, 1992] using a fast digital scanning of the grey reflectance along the core. Heinrich events, in ODP 609 and other cores studied in the same area, correspond to a shift from hemipelagic foraminiferal ooze (with high light reflectance) to layers rich in dark minerals and poor in biogenic carbonate. However, the light reflectance signature is not always simple because detrital carbonate (light) may be abundant within some events [Bond et al., 1992]. The method needs a high quality photograph picture (with regular illumination of the core) or direct scanning of freshly collected sediment.

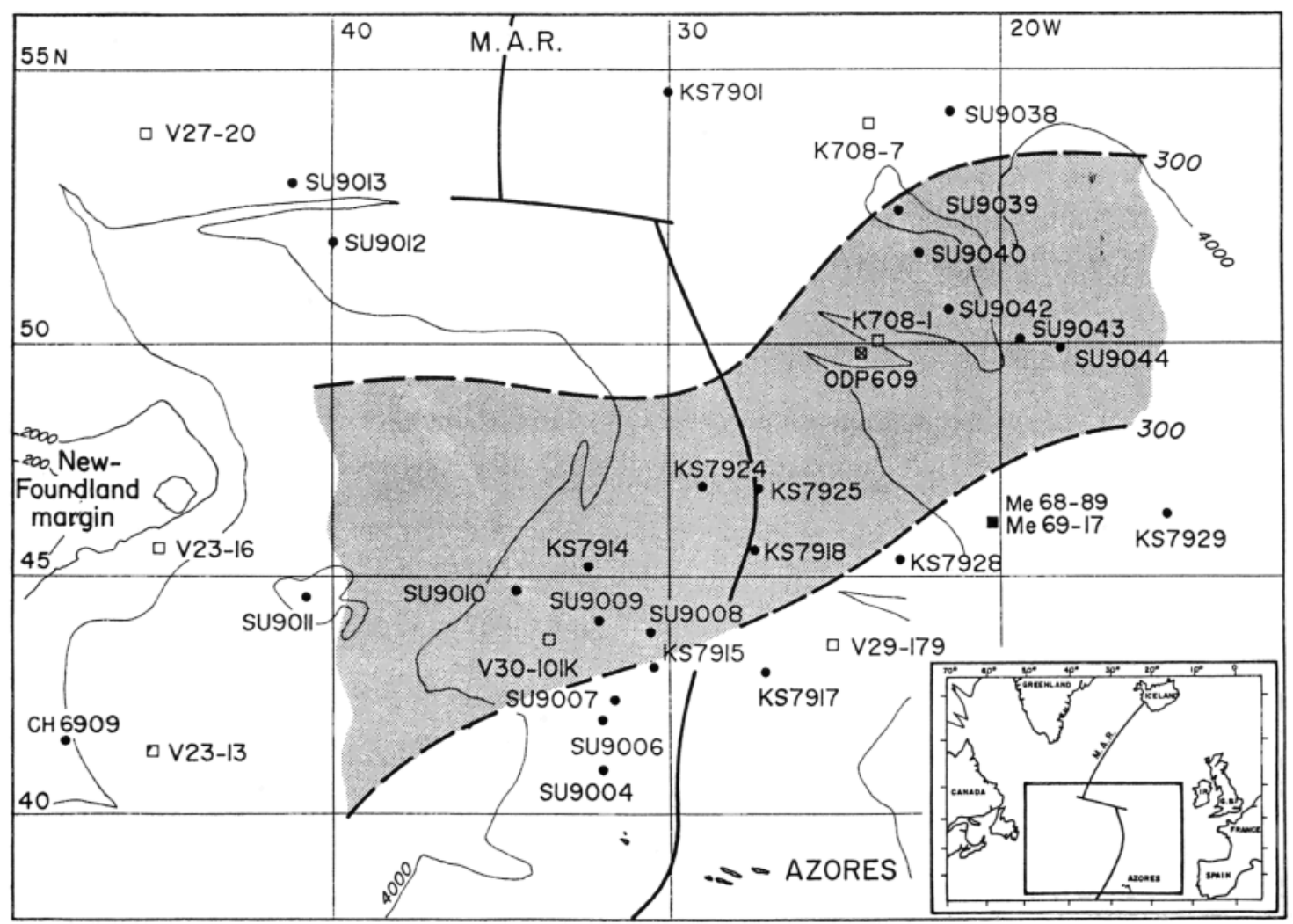

Fig. 1. Location of the cores. Symbols: french cores (solid circles); other cores: (solid squares) Heinrich [1988] and Jantschik and Huon [1992], (crossed squares) Broecker et al. [1992], (open squares) Ruddiman [1977]. Two west-east heavy dashed lines bordering the stippled envelope, define the location of the ice-rafted detritus belt during isotope stage 2 [after Ruddiman, 1977]. Within this belt, the rate of deposition of ice-rafted sand is greater than $300 \mathrm{mg} \mathrm{cm}^{-2} \mathrm{kyr}^{-1}$. The $\approx \mathrm{N}$-S solid line defines the axis of the Mid-Atlantic Ridge (MAR). 
Magnetic susceptibility has been proposed as a fast and convenient way to record varying inputs of material derived from continental crust within a biogenic sediment matrix [Poutiers, 1975; Poutiers and Gonthier, 1978]. Whole-core low-field magnetic susceptibility (thereafter called magnetic susceptibility) was measured aboard ship during two cruises in the North Atlantic Ocean immediately after coring (Figure 1). All the cores within the latitudinal belt of ice-rafted detritus (IRD belt) identified by Ruddiman [1977] between $\approx 45^{\circ}$ and $\approx 55^{\circ} \mathrm{N}$, define a succession of well-marked peaks in magnetic susceptibility (some examples are plotted on the Figure 2); on the other hand, we do not observe magnetic susceptibility peaks in cores outside the IRD belt (Figure 2). The similarity of susceptibility peaks to most of the peaks in lithic detritus observed by Heinrich [1988] is striking. In this paper, we present evidence that these magnetic susceptibility changes do, in fact, record Heinrich layers.

The integrated magnetic susceptibility depends on the susceptibility and relative volume of each type of

\section{INSIDE THE IRD BELT:}

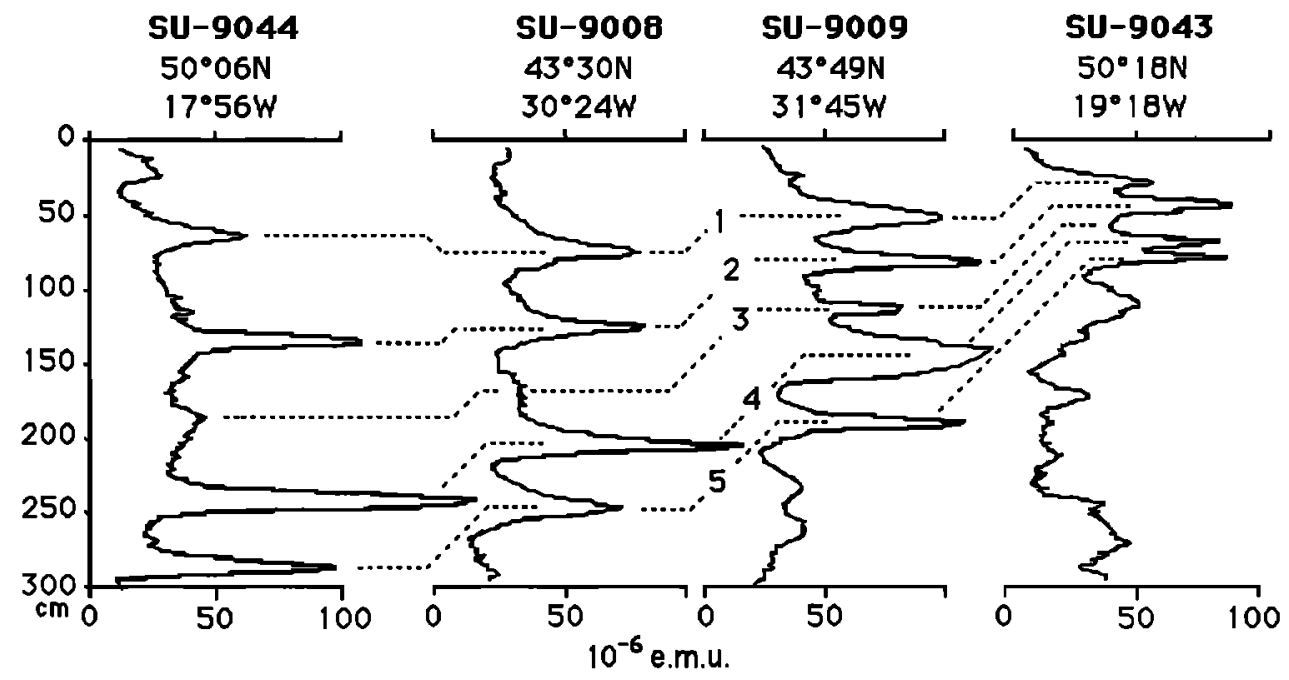

OUTSIDE THE IRD BELT:

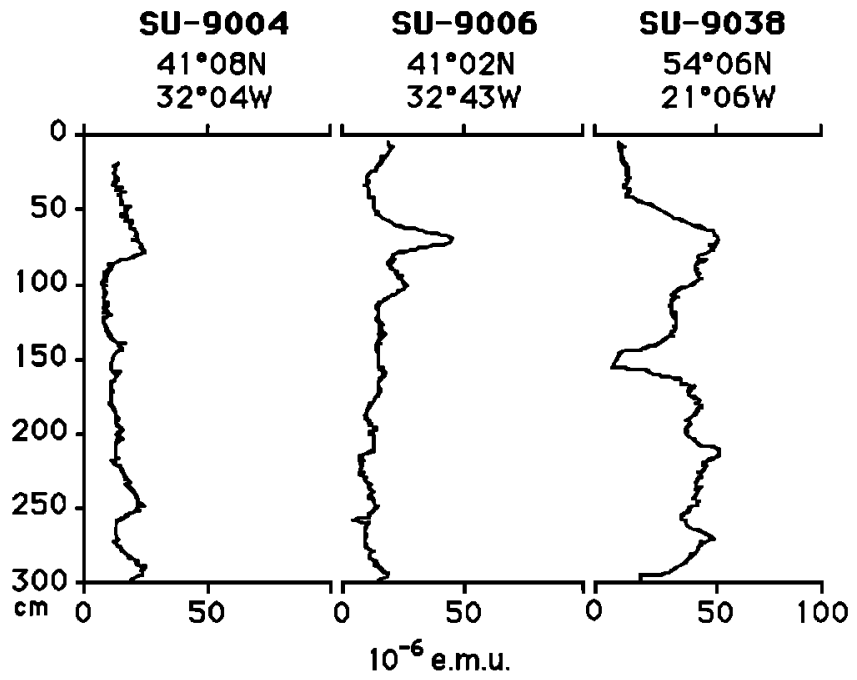

Fig. 2. Examples of low-field magnetic susceptibility profiles on uppermost $3 \mathrm{~m}$ in cores located inside and outside the ice-rafted detritus belt first recognized by Ruddiman [1977] (see location on Figure 1). Correspondences between peaks can be proposed on the basis of biostratigraphic arguments (dashed numbered lines). 
sedimentary particle and on the porosity of the sediment. Biogenic skeletons, quartz or calcite have a very low (or negative) magnetic susceptibility. In contrast, ferromagnetic and paramagnetic minerals have a high magnetic susceptibility. Possible sources of a high signal include: (1) iron- or titanium-rich magnetite [Poutiers and Gonthier, 1981], (2) goethite [Robinson, 1986], (3) iron sulfides (diagenetic minerals in organic-rich deposits) such as pyrrhotine or greigite [Poutiers, 1975]; and (4) iron-rich clay minerals [Poutiers, 1975]. Thus deposits with a large amount of biogenic material have typically low or negative magnetic susceptibility. At the opposite end of the spectrum, deposits with a large amount of icerafted detritus, especially with significant volcanic (mantle-) derived components have high magnetic susceptibility. The latter is typically the case in the North Atlantic glacial sediments. However, a fraction of the ice-rafted detritus minerals is carbonatederived from continental deposits [Bond et al., 1992] and these sediments may not appear as magnetic susceptibility peaks within the Heinrich layers.

As a first step, we checked the relationship between the magnetic susceptibility peaks and the signature of the Heinrich events. That signature consists of an increase in the proportion of material derived from the continental crust and of the lithic grains in the large size fraction $(>180 \mu \mathrm{m}$ in the work by Heinrich [1988]), the light/dark variations described by Bond et al. [1990, 1992], the changes in absolute abundance of foraminifera and proportion of $N$. pachyderma sin., and the presence of detrital carbonate [Bond et al., 1992].

\section{THE SU-9008 RECORDS: METHODS AND RESULTS}

Core SU-9008 was used for calibrating magnetic susceptibility to lithologic and foraminiferal variation. This 12-m core was raised from the western side of the Mid-Atlantic Ridge (MAR) $\left(\approx 43^{\circ} 30^{\prime} \mathrm{N}\right.$ and $\approx 30^{\circ} 24^{\prime} \mathrm{W}, 3.1-\mathrm{km}$ water depth). Stratigraphy was provided by $\delta^{18} 0$ isotopic analysis performed at $5 \mathrm{~cm}$ intervals on the planktonic foraminifera Globigerina bulloides (Figure 3a, Table 1). The core top values are consistent with the expected presentday values for this species and location [Duplessy et al., 1991]. Reference ages were derived from the $\delta^{18} 0$ record by detailed correlation of stages with the SPECMAP stacked $\delta^{18} 0$ signal [Martinson et al., 1987]; intermediate ages are estimated by polynomial interpolations between SPECMAP ages of Martinson et al. [1987]. The $\delta^{18} 0$ values are reported versus sediment depth (centimeters) and estimated age (kiloyears) in Table 2. We have identified ash-zone I $(\approx 10.5 \mathrm{kyr}$ B.P. $-50 \mathrm{~cm})$ and II $(\approx 60 \mathrm{kyr}$ B.P. -340 cm) [Ruddiman and Glover, 1972] which although barely visible at this southern latitude, provide additional age control. The core covers about 260 $\mathrm{kyr}$, which corresponds to a mean accumulation rate of $\approx 4.6 \mathrm{~cm} \mathrm{kyr}^{-1}$. Our samples are thus spaced at about $1 \mathrm{kyr}$ intervals.

Whole-core low-field magnetic susceptibility was measured aboard ship with a pass-through Bartington magnetometer. This instrument integrates the sediment section within the coil $(12.5 \mathrm{~cm}$ diameter for SU-9008). Without deconvolution, the resolution of the signal is only about $5-10 \mathrm{~cm}$. In addition, the same instrument was used with a smaller coil $(4 \mathrm{~cm}$ diameter), to record the changes in magnetic susceptibility along a continuous subsampling of core SU9008. The sampling was done using a transparent PVC U-shaped channel. Resolution after deconvolution of the signal is of the order of $\approx 2 \mathrm{~cm}$ (Figure $3 \mathrm{~b})$. Five well-defined peaks are recorded for the last glacial period (isotopic stages 4 to 2), and smaller peaks appear in the preceeding glacial sediment. Within the uppermost two peaks, we separated the magnetic particles with an electromagnet (Franz separator). When observed under scanning microscope with EDAX, these particles appear as small Feand Ti-magnetite grains, associated with crustderived feldspars. Measurements of the magnetic susceptibility of these grains reveal that they bear more than $50 \%$ of the total susceptibility signal.

The input of material derived from the continent ("terrigenous") has been quantified as follows. Water content (percent) was measured on known volumes of freshly retrieved sediment, allowing calculation of the bulk dry density of each sample $\left(\mathrm{g} \mathrm{cm}^{-3}\right) . \mathrm{CaCO}_{3}$ content (\%) was obtained by the gasometric method. Using these data and accumulation rates $\left(\mathrm{cm} \mathrm{kyr}^{-1}\right)$ derived from the $\delta^{18} \mathrm{O}$ stratigraphy, we calculated terrigenous (carbonate-free) fluxes (in $\mathrm{g} \mathrm{cm}^{-2} \mathrm{kyr}^{-1}$ ) (Figure 3c). We are fully aware of the inaccuracy of such a calculation; a better evaluation would require radiocarbon datings. However, considering these fluxes as a first order approach, increase in the terrigenous flux by a factor 2 or 3 occurs at the same depths as the magnetic susceptibility peaks. This procedure apparently is too coarse to identify the reduction in foraminifera fluxes within the uppermost three IRD peaks that was found by Bond et al. [1992].

The grey level reflectance of core SU-9008 has been analyzed following Bond et al. [1992]. The relative scale varies from white (0) to black (256). The record is reported on Figure 4a for the uppermost $400 \mathrm{~cm}$ in relation to the magnetic susceptibility signal. A clear relationship exists between the grey scale and susceptibility, at least in the depth distribution of the peaks. The grey-scale structure of core SU-9008 is similar enough to the ODP 609 record of Bond et al. [1992] to infer the position of most of the Heinrich layers (HL1 to 6) in SU-9008, with only HL3 not well represented (Figure 5).

We counted lithic grains (as percent abundance over total number of lithics plus foraminifera shells) in the $>150 \mu \mathrm{m}$ fraction, down to $320 \mathrm{~cm}$ depth (Table 2). Well-defined IRD peaks (up to $\approx 75$ to 

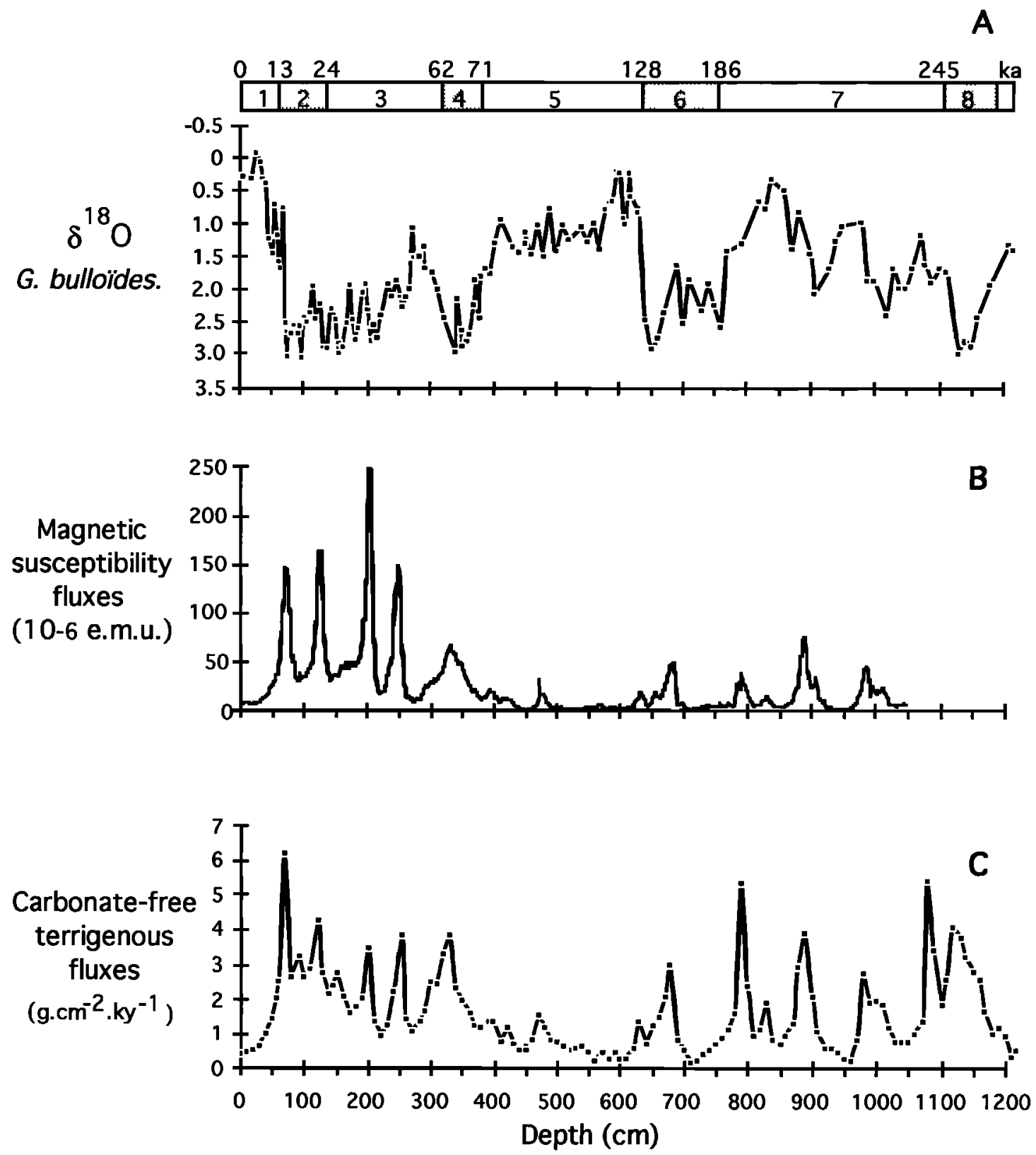

Fig. 3. Core SU-9008 $\left(43^{\circ} 30^{\prime} \mathrm{N}, 30^{\circ} 24^{\prime} \mathrm{W}, 3.1 \mathrm{~km}\right.$ depth): (a) $\delta^{18} \mathrm{O}$ of planktic foraminifera $G$. bulloides $(>150 \mu \mathrm{m})$, and isotopic stages derived from this record in the entire core $(12 \mathrm{~m}) ;(\mathrm{b})$ low-field magnetic susceptibility flux (in 10-6 electromagnetic units $\mathrm{cm}^{-2} \mathrm{kyr}^{-1}$ ); (c) terrigenous (carbonate-free fraction) flux (in $\mathrm{g} \mathrm{cm}^{-2} \mathrm{kyr}^{-1}$ ).

95\% lithic grains of this size fraction) are present within the same depth ranges as the grey scale reflectance and magnetic susceptibility peaks (Figure $4 a)$. Microscopic observation and $X$ ray diffraction of the lithic fraction corresponding to the peaks allowed us to identify quartz, micas and numerous crust-derived minerals among ubiquitous brown volcanic shards. The coarsest grains (millimeter-to- centimeter) have various petrological compositions (sandstone, basalt, granite, gneiss...). The proportion of carbonate grains (including dolomite) was estimated using a polarizing microscope in the uppermost $220 \mathrm{~cm}$ of the core. A semi-quantitative measurement was obtained by observing 50 grains, through cross-nichols, and counting the number of carbonate grains therein (Figure 4d). The relative 
TABLE 1 . Results from core SU-9008

\begin{tabular}{|c|c|c|c|c|}
\hline $\begin{array}{l}\text { Level, } \\
\mathrm{cm}\end{array}$ & $\begin{array}{c}\mathrm{Cac03} \\
\%\end{array}$ & 2180 & $\begin{array}{l}\text { Age, } \\
\text { kyr }\end{array}$ & $\begin{array}{l}\text { Terri. flux, } \\
\text { g cm-2 kyr-1 }\end{array}$ \\
\hline 2 & 89 & & 0.4 & 0.44 \\
\hline 8 & 88 & 0.29 & 1.9 & 0.49 \\
\hline 20 & 87 & 0.32 & 4.2 & 0.55 \\
\hline 32 & 84 & & 6.6 & 0.67 \\
\hline 40 & 76 & 0.41 & 8.4 & 0.99 \\
\hline 50 & 66 & 1.34 & 10.5 & 1.48 \\
\hline 58 & 55 & 0.95 & 12.1 & 1.82 \\
\hline 62 & 48 & 1.14 & 12.8 & 2.25 \\
\hline 70 & 32 & & 14.5 & 4.70 \\
\hline 80 & 50 & 3.00 & 15.7 & 2.08 \\
\hline 92 & 51 & 2.7 & 17.1 & 6.49 \\
\hline 100 & 48 & & 18.1 & 8.17 \\
\hline 110 & 46 & 2.83 & 19.3 & 8.81 \\
\hline 122 & 36 & 2.64 & 20.8 & 12.08 \\
\hline 130 & 40 & & 22.4 & 2.86 \\
\hline 140 & 45 & 2.61 & 24.0 & 2.22 \\
\hline 146 & 42 & 2.0 & 25.3 & 2.35 \\
\hline 150 & 40 & 1.98 & 26.0 & 2.82 \\
\hline 162 & 45 & $\mathbf{2 . 6}$ & 28.0 & 1.91 \\
\hline 170 & 48 & 2.85 & 30.5 & 1.51 \\
\hline 180 & 48 & & 33.3 & 1.70 \\
\hline 192 & 45 & 1.99 & 36.7 & 1.85 \\
\hline 200 & 29 & & 39.1 & 3.39 \\
\hline 210 & 58 & 2.5 & 41.8 & 1.28 \\
\hline 222 & 68 & 2.17 & 45.0 & 0.89 \\
\hline 230 & 60 & 1.62 & 47.4 & 1.19 \\
\hline 240 & 50 & 1.53 & 50.2 & 2.11 \\
\hline 252 & 39 & 1.76 & 52.3 & 3.78 \\
\hline 260 & 72 & 1.59 & 53.7 & 1.38 \\
\hline 270 & 80 & 1.26 & 55.4 & 1.03 \\
\hline 282 & 80 & & 57.1 & 1.27 \\
\hline 290 & 75 & 1.76 & 58.2 & 1.69 \\
\hline 300 & 61 & 1.76 & 59.5 & 2.59 \\
\hline 309 & 64 & 2.03 & 60.8 & 2.43 \\
\hline 320 & 51 & 2.46 & 62.2 & 3.17 \\
\hline 329 & 41 & & 63.5 & 3.54 \\
\hline 340 & 48 & 2.98 & 65.0 & 2.48 \\
\hline 350 & 50 & 2.85 & 67.0 & 1.82 \\
\hline 360 & 57 & & 69.1 & 1.51 \\
\hline 370 & 66 & & 71.1 & 1.29 \\
\hline 379 & 70 & 1.82 & 72.9 & 1.14 \\
\hline 390 & 67 & & 75.2 & 1.33 \\
\hline 399 & 68 & 1.17 & 77.0 & 1.37 \\
\hline 410 & 83 & 0.95 & 79.3 & 0.81 \\
\hline 420 & 77 & & 80.9 & 1.23 \\
\hline 431 & 87 & 1.36 & 82.8 & 0.68 \\
\hline 440 & 90 & 1.45 & 84.3 & 0.51 \\
\hline 449 & 89 & 1.3 & 85.8 & 0.57 \\
\hline 450 & 91 & 1.15 & 85.9 & 0.53 \\
\hline 459 & 85 & 1.48 & 87.4 & 0.83 \\
\hline 470 & 71 & 1.04 & 89.3 & 1.53 \\
\hline 480 & 81 & 1.5 & 91.0 & 1.18 \\
\hline 489 & 90 & & 92.0 & 0.78 \\
\hline 500 & 68 & 1.42 & 93.4 & 0.75 \\
\hline 509 & 91 & 1.04 & 94.4 & 0.64 \\
\hline 520 & 92 & 1.26 & 95.8 & 0.58 \\
\hline 530 & 91 & & 97.0 & 0.67 \\
\hline 539 & 91 & 1.07 & 98.1 & 0.66 \\
\hline 550 & 86 & 1.27 & 99.4 & 0.40 \\
\hline 559 & 87 & 1.01 & 104.5 & 0.20 \\
\hline 570 & 78 & 1.38 & 110.8 & 0.44 \\
\hline 579 & 91 & 0.76 & 113.1 & 0.31 \\
\hline 590 & 6.4 & & 116.0 & 0.47 \\
\hline
\end{tabular}

TABLE 1. (continued)

\begin{tabular}{|c|c|c|c|c|}
\hline $\begin{array}{l}\text { Level, } \\
\mathrm{cm}\end{array}$ & $\begin{array}{c}\mathrm{CaCO3} \\
\%\end{array}$ & 2180 & $\begin{array}{l}\text { Age, } \\
\text { kyr }\end{array}$ & $\begin{array}{l}\text { Terri. flux, } \\
\text { g cm-2 kyr-1 }\end{array}$ \\
\hline 600 & 90 & & 118.6 & 0.36 \\
\hline 609 & 91 & 0.58 & 121.0 & 0.31 \\
\hline 620 & 80 & 0.24 & 123.8 & 0.57 \\
\hline 630 & 42 & & 127.5 & 1.36 \\
\hline 640 & 66 & 2.47 & 131.5 & 0.69 \\
\hline 650 & 55 & 2.93 & 135.1 & 1.31 \\
\hline 661 & 64 & 2.76 & 142.2 & 1.45 \\
\hline 670 & 55 & 2.35 & 148.1 & 2.05 \\
\hline 679 & 38 & & 153.9 & 2.88 \\
\hline 690 & 60 & 1.63 & 161.3 & 0.78 \\
\hline 699 & 54 & 2.53 & 164.2 & 0.52 \\
\hline 710 & 87 & 1.85 & 167.7 & 0.18 \\
\hline 719 & 81 & & 170.6 & 0.24 \\
\hline 730 & 65 & 2.33 & 174.1 & 0.45 \\
\hline 740 & 60 & 1.92 & 177.1 & 0.51 \\
\hline 750 & 62 & 2.25 & 180.4 & 0.67 \\
\hline 759 & 75 & 2.59 & 183.3 & 0.83 \\
\hline 771 & 67 & 1.42 & 185.6 & 1.04 \\
\hline 780 & 74 & & 187.4 & 1.58 \\
\hline 791 & 67 & 1.3.t & 189.6 & 5.51 \\
\hline 800 & 85 & & 190.2 & 2.29 \\
\hline 809 & 94 & & 190.9 & 0.89 \\
\hline 820 & 93 & 0.67 & 191.7 & 1.19 \\
\hline 830 & 88 & 0.77 & 192.4 & 1.90 \\
\hline 639 & 93 & 0.34 & 193.0 & 0.82 \\
\hline 850 & 91 & & 194.2 & 0.70 \\
\hline 859 & 89 & 0.51 & 195.2 & 0.94 \\
\hline 870 & 85 & 1.38 & 196.4 & 1.35 \\
\hline 880 & 67 & 0.84 & 197.5 & 2.94 \\
\hline 889 & 54 & & 198.4 & 3.75 \\
\hline 900 & 76 & 1.46 & 199.6 & 1.97 \\
\hline 909 & 62 & 2.06 & 200.6 & 1.03 \\
\hline 920 & 74 & & 205.6 & 0.59 \\
\hline 930 & 82 & 1.66 & 208.2 & 0.58 \\
\hline 939 & 87 & 1.24 & $2 t 0.5$ & 0.44 \\
\hline 950 & 92 & 1.03 & $2+3.3$ & 0.28 \\
\hline 959 & 94 & & 215.5 & 0.27 \\
\hline 969 & 86 & & 217.1 & 0.84 \\
\hline 980 & 60 & 0.97 & 218.8 & 2.71 \\
\hline 989 & 67 & 1.85 & 220.2 & 1.89 \\
\hline 1001 & 65 & 1.85 & 222.0 & 1.96 \\
\hline 1010 & 67 & & 223.5 & 1.84 \\
\hline 1019 & 67 & 2.38 & 224.9 & 1.21 \\
\hline 1030 & 73 & 1.68 & 228.1 & 0.70 \\
\hline 1039 & 74 & 1.96 & 230.6 & 0.78 \\
\hline 1050 & 72 & 1.98 & 234.0 & 0.83 \\
\hline 1060 & 65 & 1.66 & 236.8 & 1.03 \\
\hline 1071 & 67 & 1.18 & 240.2 & 1.41 \\
\hline 1080 & 37 & 1.62 & 244.0 & 5.46 \\
\hline 1089 & 49 & 1.88 & 248.1 & 3.24 \\
\hline 1100 & 68 & 1.66 & 253.0 & 1.87 \\
\hline 1110 & 54 & 1.73 & 256.9 & 2.69 \\
\hline 1119 & 33 & & 260.7 & 3.93 \\
\hline 1130 & 32 & 2.97 & 265.7 & 3.63 \\
\hline 1139 & 41 & 2.76 & 268.2 & 3.13 \\
\hline 1150 & 49 & 2.85 & 271.4 & 2.83 \\
\hline 1160 & 54 & 2.43 & 274.1 & 2.64 \\
\hline 1169 & 70 & & 276.7 & 1.65 \\
\hline 1180 & 83 & 1.92 & 280.0 & 0.98 \\
\hline 1189 & 81 & & 282,5 & 1.20 \\
\hline 1200 & 85 & & 285.7 & 0.97 \\
\hline $12+0$ & 95 & 1.32 & 288.5 & 0.37 \\
\hline 1218 & $9 t$ & 1.4 & 290.8 & 0.55 \\
\hline
\end{tabular}


TABLE 2. Lithic Grain and Foraminifera Shell Counts in Core SU-9008

\begin{tabular}{|c|c|c|c|c|c|c|c|c|}
\hline $\begin{array}{l}\text { Depth, } \\
\text { cm }\end{array}$ & $\begin{array}{c}\text { N.pachy. } \\
\text { (sin.), } \\
\text { number }\end{array}$ & $\begin{array}{c}\text { N.pachy. } \\
\text { (sin.). } \\
(\%)\end{array}$ & $\begin{array}{c}\text { Other } \\
\text { Forams, } \\
\text { number }\end{array}$ & $\begin{array}{l}\text { Lithic } \\
\text { Grains, } \\
\text { number }\end{array}$ & $\begin{array}{c}\text { Lithic } \\
\text { Grains, } \\
\%\end{array}$ & $\begin{array}{l}\text { Lithic Grains } \\
/ g .(>150 \mu \mathrm{m})\end{array}$ & $\begin{array}{c}\text { Forams } \\
/ g .(>150 \mu m)\end{array}$ & $\begin{array}{l}\text { N.pachy. (sin.) } \\
/ g .(>150 \mu \mathrm{m})\end{array}$ \\
\hline 3 & 45 & 0.3 & 15795 & 360 & 2 & 202 & 8899 & 25 \\
\hline 7.5 & 0 & 0 & 40050 & 2790 & 5.6 & 435 & 6249 & 0 \\
\hline 10 & 60 & 0.4 & 13320 & 300 & 1.8 & 128 & 5694 & 26 \\
\hline 16.5 & 0 & 0 & 36450 & 2520 & 5.5 & 371 & 5360 & 0 \\
\hline 20.5 & 45 & 0.2 & 18540 & 540 & 2.5 & 208 & 7176 & 17 \\
\hline 23 & 0 & 0 & 39150 & 720 & 1.7 & 110 & 5963 & 0 \\
\hline 32 & 0 & 0 & 16875 & 495 & 2.7 & 223 & 7601 & 0 \\
\hline 34.5 & 0 & 0 & 31500 & 1170 & 3.3 & 180 & 4849 & 0 \\
\hline 40.5 & 0 & 0 & 12870 & 1230 & 7.9 & 609 & 6371 & 0 \\
\hline 44 & 180 & 0.4 & 41400 & 2610 & 5.6 & 371 & 5918 & 26 \\
\hline 50 & 180 & 0.5 & 37440 & 1800 & 4.4 & 638 & 13340 & 64 \\
\hline 56 & 5130 & 15.5 & 27900 & 6300 & 15.8 & 848 & 4448 & 691 \\
\hline 58.5 & 1350 & $\$ 1.4$ & 10500 & 3630 & 23 & 1558 & 5086 & 579 \\
\hline 62 & 3000 & 23.6 & 9720 & 4170 & 24.3 & 1341 & 4090 & 965 \\
\hline 68.5 & 2106 & 36.9 & 3600 & 19620 & 77.3 & 1675 & 487 & 180 \\
\hline 70 & 1920 & 88.9 & 240 & 27552 & 92.7 & 5887 & 462 & 410 \\
\hline 74 & 17910 & 55.9 & 14130 & 15210 & 30.8 & 2363 & 4978 & 2783 \\
\hline 80.5 & 22740 & 54.2 & 19200 & 11220 & 20.7 & 5610 & 20970 & 11370 \\
\hline 82.5 & 16200 & 41.8 & 22560 & 10320 & 20.1 & 1624 & 6101 & 2550 \\
\hline 92 & 1350 & 9.1 & 13455 & 3285 & 17.6 & 2092 & 9430 & 660 \\
\hline 94.5 & 1935 & 9.8 & 17730 & 3870 & 15.6 & 765 & 3885 & 382 \\
\hline 100.5 & 2115 & 15.8 & 11250 & 2745 & 16.2 & 1569 & 7637 & 1209 \\
\hline 104 & 3420 & 10.5 & 29070 & 6300 & 15.9 & 1177 & 6072 & 639 \\
\hline 110 & 1800 & 9 & 18120 & 6240 & 23.2 & 3104 & 9910 & 896 \\
\hline 112.5 & 2040 & 10.2 & 17880 & 7140 & 26.2 & 1262 & 3520 & 360 \\
\hline 122.5 & 2490 & 50 & 2490 & 14835 & 73.9 & 4376 & 1469 & 735 \\
\hline 124.5 & 1740 & 36.5 & 3030 & 13290 & 73.2 & 1353 & 486 & 177 \\
\hline 130 & 5760 & 29.9 & 13500 & 6300 & 24 & 3182 & 9727 & 2909 \\
\hline 134.5 & 24120 & 34.9 & 45000 & 12960 & 15.6 & 2207 & 11769 & 4107 \\
\hline 140 & 7155 & 35 & 13275 & 5490 & 20.6 & 2905 & $108+0$ & 3786 \\
\hline 142.5 & 9000 & 22 & 31860 & 3060 & 6.8 & 592 & 7908 & 1742 \\
\hline 146 & 1845 & 10.9 & 15075 & 3915 & 18.4 & 2224 & 9614 & 1048 \\
\hline 150 & 3600 & 19.2 & 15165 & 4230 & 18 & 1685 & 7476 & 1434 \\
\hline 156.5 & 11880 & 31.9 & 25380 & 5580 & 12.6 & 930 & 6211 & 1980 \\
\hline 162 & 8100 & 33 & 16470 & 3510 & 12.1 & 1972 & 13803 & 4551 \\
\hline 168 & 12060 & 25.9 & 34470 & 1620 & 3.3 & 257 & 7392 & 1916 \\
\hline 170 & 6525 & 33 & 13275 & 1485 & 6.7 & 863 & 11512 & 3794 \\
\hline 177 & 8190 & 29.8 & 19260 & 2250 & 7.3 & 349 & 4258 & 1270 \\
\hline 180 & 4590 & 24.9 & 13815 & 1665 & 7.9 & 715 & 7899 & 1970 \\
\hline 189.5 & 3195 & 18.8 & 13815 & 2295 & 11.6 & 342 & 2537 & 477 \\
\hline 192 & 4032 & 35 & 7488 & 2844 & 18.8 & 1166 & 4721 & 1652 \\
\hline 199 & 9000 & 37.4 & 15048 & 12384 & 33.4 & 1434 & 2784 & 1042 \\
\hline 201.5 & 816 & 77.9 & 232 & 17900 & 94.2 & 3825 & 224 & 174 \\
\hline 207.5 & 8760 & 21.9 & 31200 & 22920 & 35.2 & 2562 & 4467 & 979 \\
\hline $2+0$ & 11520 & 26.9 & 31320 & 3960 & 8 & 1517 & 16414 & 4414 \\
\hline 217 & 3150 & 9.9 & 28620 & 1440 & 4.1 & 252 & 5564 & 552 \\
\hline 222.5 & 3510 & 11.9 & 26100 & 1620 & 5 & 947 & 17316 & 2053 \\
\hline 225 & 10260 & 17.5 & 48420 & 3600 & 5.2 & 578 & 9416 & 1646 \\
\hline 230 & 2100 & 10.4 & 18060 & 300 & 1.4 & 106 & 7124 & 742 \\
\hline 237 & 1350 & 7.7 & 16200 & 3195 & 14.7 & 446 & 2448 & 188 \\
\hline 240 & 1890 & 13.5 & 12150 & 6330 & 30.3 & 2512 & 5571 & 750 \\
\hline 249.5 & 6480 & 22.4 & 22500 & 17550 & 37.1 & 2169 & 3582 & 801 \\
\hline 252 & 2070 & 13 & 13815 & 4410 & 20.3 & 1633 & 5883 & 767 \\
\hline 259 & 2070 & 5 & 39240 & 2070 & 4.4 & 315 & 6280 & 315 \\
\hline 261.5 & 765 & 3.4 & 21510 & 765 & 3.1 & 377 & 10973 & 377 \\
\hline 267.5 & 180 & 0.7 & 24180 & 540 & 2 & 92 & 4133 & 31 \\
\hline 270 & 270 & 1.8 & 14490 & 3555 & 19.3 & 1852 & 7688 & 141 \\
\hline 277 & 240 & 0.5 & 47160 & 960 & 1.9 & 156 & 7680 & 39 \\
\hline 282 & 900 & 5 & 17055 & 180 & 0.9 & 90 & 8933 & 448 \\
\hline 285.5 & 1440 & 2.5 & 55080 & 3240 & 5.2 & 549 & 9568 & 244 \\
\hline 292 & 1125 & 13 & 7560 & 922,5 & 8.9 & 323 & 3037 & 393 \\
\hline 295 & 4050 & 12.9 & 27270 & 1890 & 5.4 & 251 & 4162 & 538 \\
\hline 300 & 2790 & 17.1 & 13500 & 1980 & 26.3 & 892 & 7330 & 1257 \\
\hline 309 & 6075 & 24.5 & 18765 & 1890 & 14.2 & 969 & 12738 & 3115 \\
\hline 320 & 6300 & 40.2 & 9360 & 6165 & 28.1 & 2258 & 5736 & 2308 \\
\hline
\end{tabular}


- Grey level $\begin{array}{r}\text { dark } 260 \\ 240 \\ 220 \\ 200 \\ \hline\end{array}$

- Magnetic susceptibility fluxes (10-6 e.m.u.)
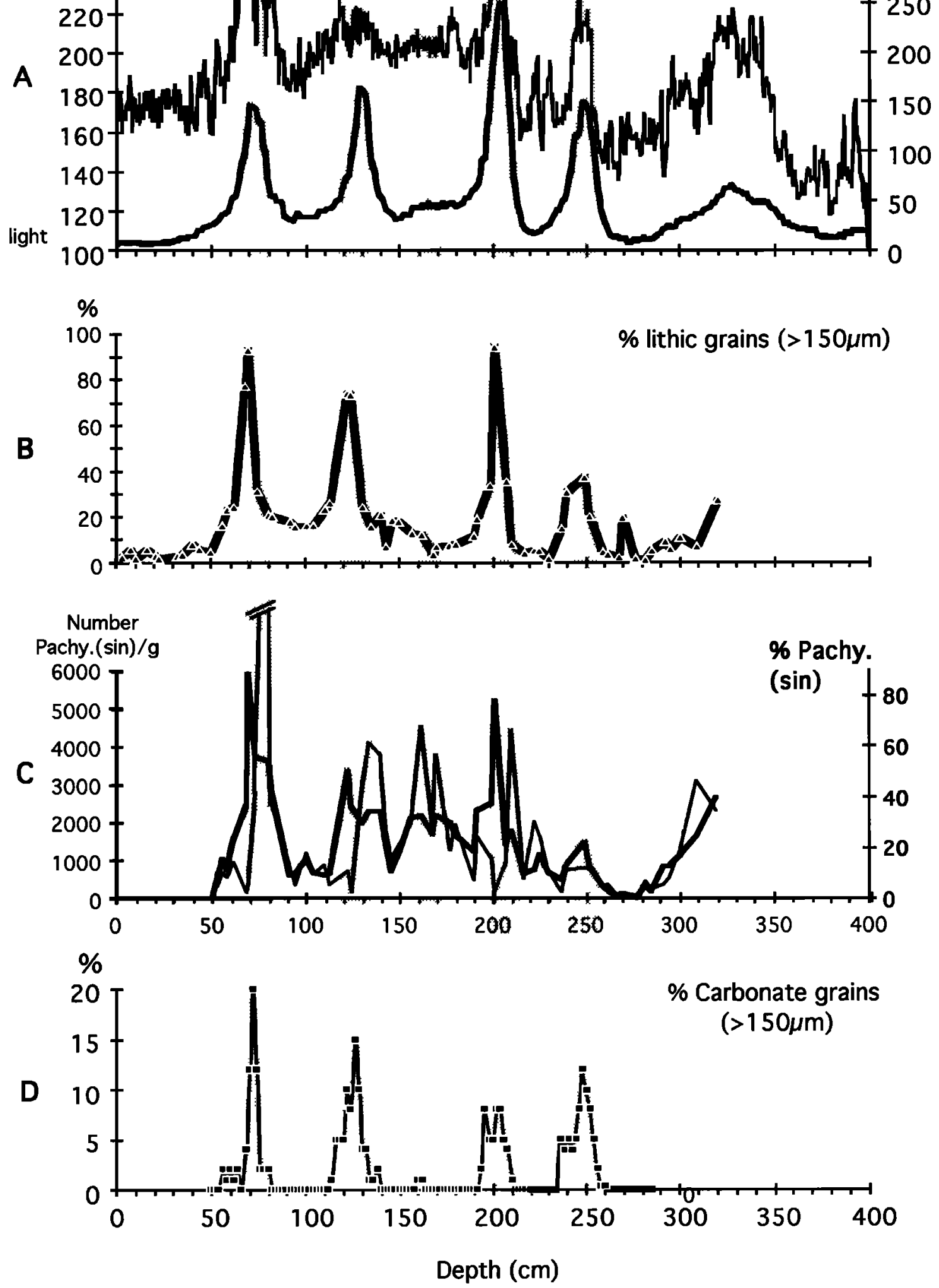
proportions of detrital carbonate grains display peaks (up to $10-20 \%$ of the lithic fraction), in phase with the proportion of lithics and the magnetic susceptibility peaks in HL1, HL2, HL4 and HL5. They are rare to absent between the peaks and in HL3. Similar results were reported by Bond et al. [1992] in cores from the eastern North Atlantic. In cores from the western north Atlantic, however, Bond et al. [1992] found layers rich in detrital carbonate in HL3.

We estimated the absolute amounts of the foraminiferal species: Neogloboquadrina pachyder$m a$ sin. This species dominates the foraminifera population in cold surface waters. Sharp increase in $N$. pachyderma sin. relative abundance (percent of the foraminifera content) is associated with the lithic and magnetic susceptibility peaks (Figure 4c), as expected for the classical description of Heinrich events [Heinrich, 1988; Bond et al., 1992]. On the other hand, sharp peaks in the absolute amount of $N$. pachyderma sin. (4000 to 11,000 shells/gram) appear just below the lithic peaks $(\approx 10 \mathrm{~cm}$ below the peak maximum). All of the subevents observed within a Heinrich layer are bracketed in Figure $4(N$. pachyderma sin. relative abundance, $N$. pachyderma sin. absolute abundance, magnetic susceptibility, lithic grain, carbonate grain and darker color peaks.

One more question must be answered before associating magnetic susceptibility peaks with Heinrich's events: is the timing of the events the same in Northwest Atlantic core SU-9008 as in the northeast Atlantic records studied by Heinrich [1988] and Bond et al. [1992]? Heinrich [1988] relied on a lowresolution oxygen isotopic record. Bond et al. [1992] give detailed AMS radiocarbon dates for the first three events, and ages derived from changes in the reflectance curve -- interpreted as a proxy for seasurface temperature -- lower in site 609 (Fig.5): (1) HL1 (the uppermost Heinrich layer) is located at the base of the $\delta^{18} \mathrm{O}$ transition IA, and AMS-14 C dated between $\approx 13.4$ and $\approx 14.5 \mathrm{ka}$ in site 609 (with a -0.4 kyr correction for the ${ }^{14} \mathrm{C}$ apparent age of surface waters). This fits with the $\delta^{18} \mathrm{O}$ interpolated age of the first event $(\approx 15.4 \mathrm{kyr}$ at $70 \mathrm{~cm}$ downcore) in SU9008 (Table 1). (2) HL2 is located in the middle of isotopic stage 2 , and $\mathrm{AMS}-{ }^{14} \mathrm{C}$ dated it at. $\approx 18.9$ $21.4 \mathrm{ka}$ in ODP 609 . In core SU-9008, this second event is located at $\approx 120 \mathrm{~cm}$ and has a $\delta^{18} \mathrm{O}$ interpolated age of $\approx 20 \mathrm{kyr}$. (3) HL3 is located at the transition between isotopic stages 2 and 3 , and is dated by $\mathrm{AMS}-{ }^{14} \mathrm{C}$ between $\approx 25.6$ and $29.2 \mathrm{kyr}$ B.P. in site 609. The magnetic susceptibility and lithic grain records do not show clearly defined peaks at that level, but the peak in $N$. pachyderma sin. abundance at $\approx 165 \mathrm{~cm}$ depth could be the corresponding signature ( $\delta^{18} \mathrm{O}$ interpolated age of $\approx 27$ kyr). Moreover, the magnetic susceptibility peak can be recognized in many other cores (for instance: SU9009 in Figure 2). (4) HL4 and HL5 are located within isotopic stage 3 at $\delta^{18} \mathrm{O}$-extrapolated ages of $\approx 40$ and $\approx 50 \mathrm{ka}$ in site 609 , compared with the $\delta^{18} \mathrm{O}$ estimated ages of $\approx 38 \mathrm{kyr}$ (at $200 \mathrm{~cm}$ ) and $\approx 52 \mathrm{kyr}$ (at $250 \mathrm{~cm}$ ) in core SU-9008. (5) HL6 covers isotopic stage 4 (with a peak at $350 \mathrm{~cm}$, and an $\delta^{18} \mathrm{O}$ extrapolated age of about $67 \mathrm{ka}$ in core SU-9008) and generally displays a slight signal; it will consequently not be considered in this study.

In conclusion, the clear temporal correlation between the "classical" description of the Heinrich events and the magnetic susceptibility signature validates the use of the magnetic susceptibility records as a HL monitor.

\section{SPATIAL DISTRIBUTION OF THE HEINRICH LAYERS}

\section{Methods}

We may map the spatial distribution of the Heinrich layers during the last glacial period with the magnetic susceptibility records. Two different methods have been used for the reconstruction:

1. the first is based on the thickness of each event. To the 18 cores where the magnetic susceptibility peaks are sufficiently well-defined, we add 17 additional cores where the events have other typical signatures: lithic grain counts, quartz content, obtained from the literature (Figure 1 and Table 3). Whatever the parameter we consider (abundancy, intensity, or flux), thickness is measured in centimeters, at midheight of peaks identified on these different records. In some other cores, Ruddiman [1977] observed such a negligible amount of IRD, that we consider them as HL-free cores.

2. the second is based on the distribution of the integrated magnetic susceptibility over each peak. This value is obtained by multiplying the maximum value of the magnetic susceptibility peak $\left(10^{-6}\right.$ electromagnetic units), by the thickness (centimeters) of

Fig. 4. Core SU-9008: focus on the uppermost $400 \mathrm{~cm}$; (a) grey level pattern (relative scale from white (0) to black (256)), along with low-field magnetic susceptibility flux (in $10^{-6}$ electromagnetic units $\mathrm{cm}^{-2} \mathrm{kyr}^{-1}$ ). Dark bands highlight the Heinrich layers (HL); (b) proportion of lithic grains in the $>150 \mu \mathrm{m}$ fraction. (c) number per gram (thin line) and percentage (thick line) of $N$. pachyderma (sinistral), in the $>150 \mu \mathrm{m}$ fraction. (d) proportion (percent) of detrital carbonate grains in the coarse lithic fraction $(>150 \mu \mathrm{m})$, counted only between 50 and $320 \mathrm{~cm}$. 


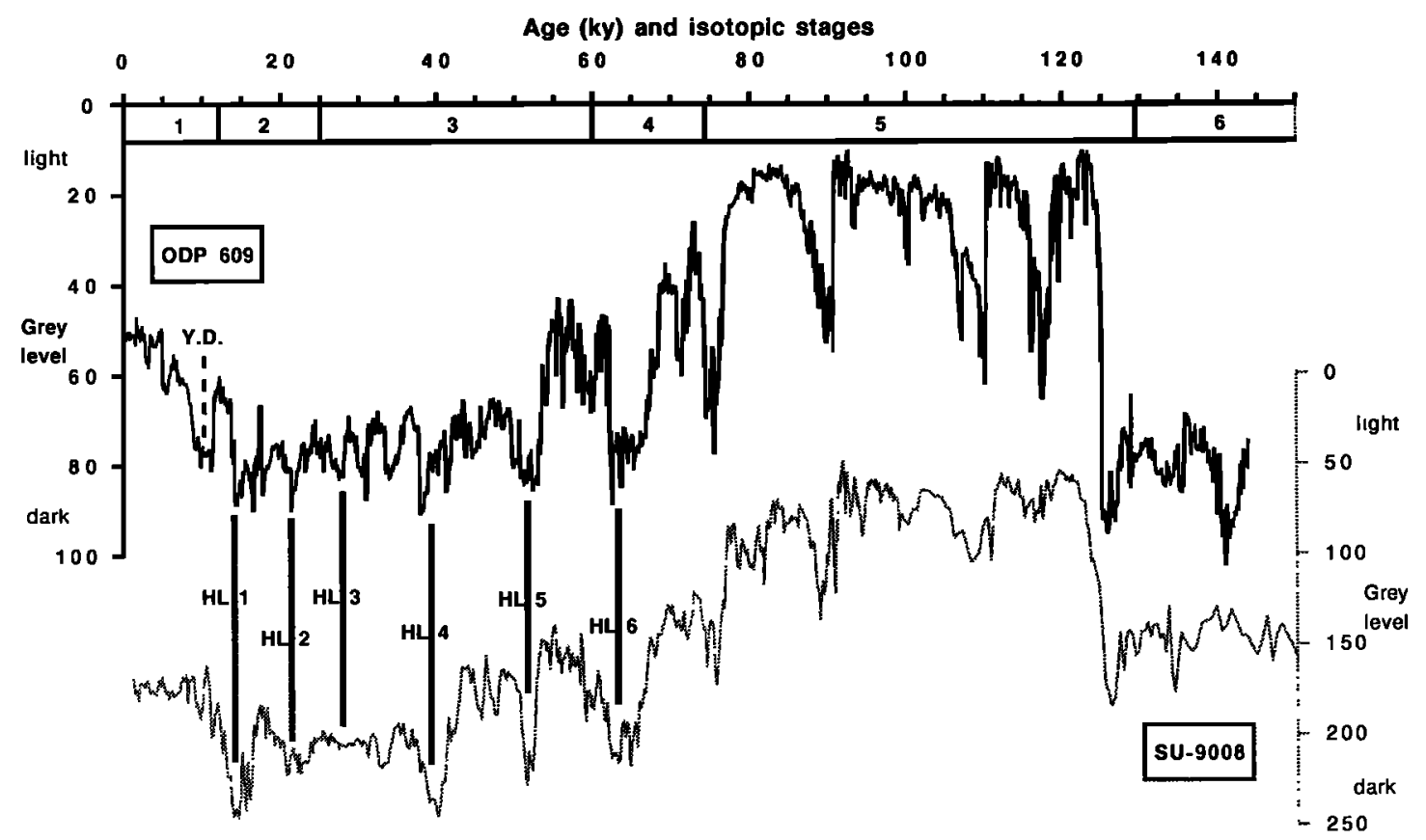

Fig. 5. Comparison of the grey scale records obtained on both cores ODP 609 (thick line) and SU9008 (thin line). Ages are derived from radiocarbon ages measured in core ODP 609 [Bond et al., 1992]. The age-scale proposed for SU-9008 is constrained by this correlation.

the peak measured at midheight. If we assume that, for each Heinrich event, the duration was about the same in each core, we may consider this integrated magnetic susceptibility value as a flux value. These measurements were available on 18 cores.

The first method is based on a much larger set of cores but is less rigorous, because we did not demonstrate that the different indicators (lithic grain counts, quartz content, etc.) have the same temporal distribution. The second method gives more quantitative and homogeneous data but only 18 cores are available. Geographical limits of the Heinrich layer zones are also constrained following the observations of Ruddiman [1977], using cores with negligible amounts of ice-rafted detritus as external boundaries (Figure 1). Only the five most recent events are considered for the reconstruction, because many cores do not reach isotopic stage 4.

\section{Results}

The short events of ice-rafted detritus accumulation identified by Heinrich [1988] in the northeast Atlantic during the last glacial period, and recently documented in a high-resolution study by Broecker et al. [1992], are not a local pattern but occur roughly between $40^{\circ} \mathrm{N}$ and $55^{\circ} \mathrm{N}$, across the entire North Atlantic. The definition of the zone of high deposition of ice-rafted detritus by Ruddiman [1977] is coherent with the zone in which the peaks of magnetic susceptibility are well defined (Figures 1, 6 and 7). It can thus be assumed that this zone is coincident with the Heinrich layers for the last glacial period. The patterns are mostly characterized by decreasing west-to-east gradients, elongated around the latitude $\approx 45^{\circ} \mathrm{N}$, except for HL3 which is oriented slightly NW-SE. This slight shift of the HL3 pattern is a possible reason for which there is no HL 3 event in core SU-9008, although the pattern of HL3 may be interpreted differently [see Bond et al., 1992]. All patterns appear to follow the southern limits of the polar waters defined by the high abundance (both \% and flux) of $N$. pachyderma sin. Their axis shifts northward by $\approx 2^{\circ}$ latitude, for example, from HL2 $\left(\approx 45^{\circ} \mathrm{N}\right)$, which is at the peak corresponding to the last glacial maximum, to HL5 $\left(\approx 47^{\circ} \mathrm{N}\right)$, which occurred during interstadial stage 3 (Figures 6 and 7).

\section{POTENTIAL ORIGINS FOR THE HEINRICH LAYERS MATERIAL}

The observed flux gradients are consistent with input by icebergs transported and melted along the southern margin of a large cyclonic gyre covering the northern Atlantic ocean during the glacial period. However, more than one source of the IRD in these layers is possible. A Canadian provenance is probable for HL1, HL2, HL4 and HL5, based on the abundance and thickness variations of layers (see gradients on Figures 6 and 7 and in the work by Bond et al. [1992]). Owing to the low content of detrital carbonate in HL3, the IRD in this layer may have had a different source (Irminger Basin? Greenland Basin?), but we do not have enough cores to 
TABLE 3. Thickness and Magnetic Susceptibility Flux of Each Heinrich Layer

\begin{tabular}{|c|c|c|c|c|c|c|c|}
\hline \multirow{3}{*}{ Cores } & \multicolumn{2}{|c|}{ HL 1} & \multicolumn{2}{|c|}{ HL 2} & \multicolumn{2}{|c|}{ HL 3} & \multirow{3}{*}{ Source $t$} \\
\hline & Thickness, & $\begin{array}{c}\text { Magnetic } \\
\text { Susceptibility }\end{array}$ & Thickness, & $\begin{array}{c}\text { Magnetic } \\
\text { Susceptibility }\end{array}$ & Thickness & $\begin{array}{c}\text { Magnetic } \\
\text { Susceptibility }\end{array}$ & \\
\hline & $\mathrm{cm}$ & Flux * & $\mathrm{cm}$ & Flux * & $\mathrm{cm}$ & & \\
\hline ME 69-17 & 7 & & 9 & & 6 & & 1 \\
\hline ODP 609 & 6 & & 5 & & 15 & & 2 \\
\hline KS 7901 & no HL & & no $H L$ & & no HL & & 4 \\
\hline KS 7914 & 32 & 2528 & 54 & 5184 & 38 & 3838 & 3 \\
\hline KS 7915 & 10 & 850 & 12 & 972 & 8 & & 3 \\
\hline KS 7917 & 7 & 112 & 7 & 140 & 6 & 480 & 3 \\
\hline KS 7918 & 20 & 1800 & 10 & 900 & 30 & 6000 & 3 \\
\hline KS 7924 & 9 & 567 & 18 & 2160 & 40 & 5400 & 3 \\
\hline KS 7925 & $\S$ & & 20 & 2480 & 20 & 1200 & 3 \\
\hline KS 7928 & 12 & 960 & 12 & 1464 & 8 & 1600 & 3 \\
\hline KS 7929 & 6 & 432 & 4 & 264 & 3 & 80 & 3 \\
\hline SU-9004 & no HL & & no HL & & no HL & & 4 \\
\hline SU-9008 & 16 & 1280 & 12 & 996 & & & 4 \\
\hline SU-9011 & $\$$ & & 30 & 4440 & 9 & 882 & 4 \\
\hline SU-9012 & no $H L$ & & no $H L$ & & no HL & & 4 \\
\hline SU-9013 & no HL & & no HL & & no $H L$ & & 4 \\
\hline SU-9039 & 8 & 864 & 6 & 312 & 3 & 126 & 4 \\
\hline SU-9040 & 1 & 50 & 13 & 1079 & 4 & 212 & 4 \\
\hline SU-9043 & 3 & 174 & 12 & 1056 & & & 4 \\
\hline SU-9044 & 12 & 756 & 10 & 1080 & 8 & 376 & 4 \\
\hline CH 6909 & 23 & & 62 & & & & 5 \\
\hline V23-16 & 25 & & 35 & & & & 6 \\
\hline
\end{tabular}

TABLE 3. (continued)

\begin{tabular}{|c|c|c|c|c|c|}
\hline \multirow[b]{2}{*}{ Cores } & \multicolumn{2}{|c|}{ HL 4} & \multicolumn{2}{|c|}{ HL 5} & \multirow[b]{2}{*}{ Sourde $t$} \\
\hline & $\begin{array}{c}\text { Thickness, } \\
\text { cm }\end{array}$ & $\begin{array}{c}\text { Magnetic } \\
\text { Susceptibility } \\
\text { Flux * }\end{array}$ & $\begin{array}{c}\text { Thickness, } \\
\mathrm{cm}\end{array}$ & $\begin{array}{c}\text { Magnetic } \\
\text { Susceptibility } \\
\text { Flux * }\end{array}$ & \\
\hline ME 69-17 & 21 & & 3 & & 1 \\
\hline ODP 609 & 17 & & 13 & & 2 \\
\hline KS 7901 & no HL & & no HL & & 4 \\
\hline KS 7914 & 24 & 2832 & & & 3 \\
\hline KS 7915 & 16 & 1824 & 14 & 812 & 3 \\
\hline KS 7917 & & & 7 & 224 & 3 \\
\hline KS 7918 & 40 & 7200 & 22 & 3850 & 3 \\
\hline KS 7924 & 38 & 6308 & 27 & 4833 & 3 \\
\hline KS 7925 & 40 & 6720 & 20 & 3660 & 3 \\
\hline KS 7928 & 18 & 3150 & 17 & 1955 & 3 \\
\hline KS 7929 & 12 & 1872 & 2 & 50 & 3 \\
\hline SU-9004 & no HL & & no HL & & 4 \\
\hline SU-9008 & 10 & 1210 & 15 & 1050 & 4 \\
\hline SU-9011 & 32 & 5440 & 40 & 7440 & 4 \\
\hline SU-9012 & no $\mathrm{HL}$ & & no HL & & 4 \\
\hline SU-9013 & no $\mathrm{HL}$ & & no $\mathrm{HL}$ & & 4 \\
\hline SU-9039 & 10 & 760 & 12 & 780 & 4 \\
\hline SU-9040 & 10 & 1080 & 7 & 637 & 4 \\
\hline SU-9043 & & & 9 & 774 & 4 \\
\hline SU-9044 & 16 & 2448 & 13 & 1248 & 4 \\
\hline CH 6909 & 31 & & 15 & & 5 \\
\hline
\end{tabular}

* Magnetic susceptibility flux is measured in $10^{-6}$ e.m.u. $\mathrm{g}^{-1} \mathrm{~cm}^{-2}$

+ Sources: 1, Heinrich [1988]; 2, Broecker et al. [1992]; 3, Grousset et al. [1981];

4, this work; 5, Pastouret et al. [1975]; 6, Bond et al. [1992].

§: HL1 not sampled (upper-core missing?).

confirm this. We may get more information on origins by deciphering source fingerprints borne by IRD particles using their isotopic composition, as described below.

In order to identify better the origins of the ice rafted detritus, we have analyzed the $\mathrm{Nd}-\mathrm{Sr}$ isotopic composition of the terrigenous fraction in three cores
(SU-9008, KS-7925, KS-7929). We present here results from only core SU-9008. On Figure 8, we have plotted $\mathrm{Nd}$ isotopic ratios (as $\boldsymbol{\varepsilon}_{\mathrm{Nd}}(\mathrm{o})$ ) along with ${ }^{87} \mathrm{Sr} /{ }^{86} \mathrm{Sr}$ ratios. On this kind of plot, each sample is generally located on mixing hyperbolae, linking two end-members, or one end-member and a mixture of some others [Faure, 1986]. In our case, the first end- 

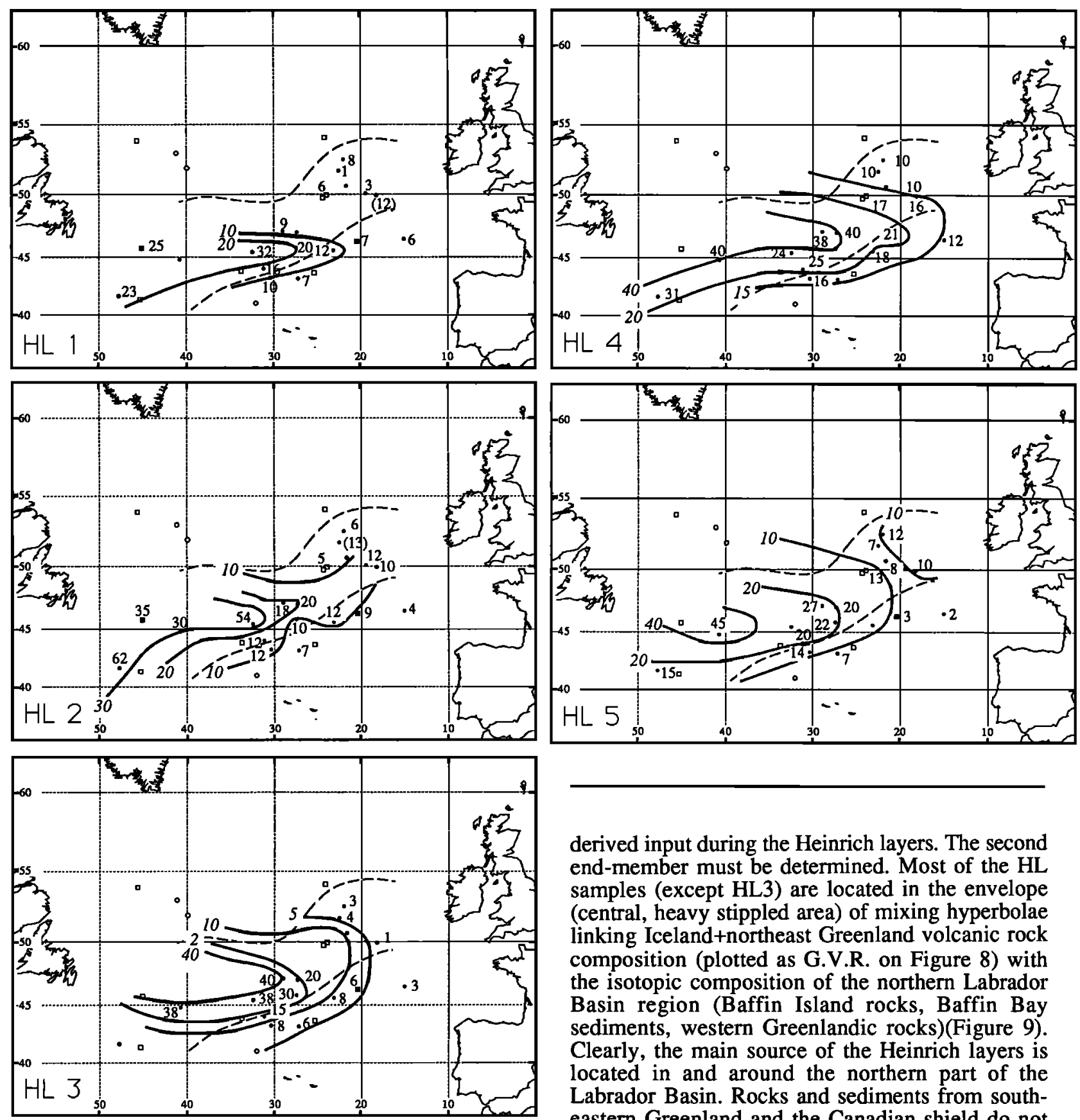

Fig. 6. Patterns of Heinrich layer thickness (in $\mathrm{cm}$ ); HL1 to HL5; ice-rafted detritus belt [after Ruddiman, 1977] is shown in dashed lines. Open symbols represent cores in which $\mathrm{HL}$ are not present.

member would be the mantle-derived provinces: Iceland and the eastern Greenland basaltic province (Figure 9). During the entire glacial period the cores have a contribution of small volcanogenic particles that may explain this contribution. However, their abundance is small compared to the large crust-

derived input during the Heinrich layers. The second end-member must be determined. Most of the HL samples (except HL3) are located in the envelope (central, heavy stippled area) of mixing hyperbolae linking Iceland+northeast Greenland volcanic rock composition (plotted as G.V.R. on Figure 8) with the isotopic composition of the northern Labrador Basin region (Baffin Island rocks, Baffin Bay sediments, western Greenlandic rocks)(Figure 9). Clearly, the main source of the Heinrich layers is located in and around the northern part of the Labrador Basin. Rocks and sediments from southeastern Greenland and the Canadian shield do not seem to be a main end-member (lower stippled envelope, Figure 8). Potential sources from the northern (Fram Strait and Arctic Ocean) and/or northeastern side of the Atlantic Ocean (Fennoscandian, Barentz and Svalbard ice sheets) may also be discarded too (upper stippled envelope, Figure 8). From classical mixing equations, it is possible to evaluate the respective contributions from the two end-members. For example, HL1 is composed of $\approx 70 \%$ "Baffin" particles (Baffin Bay sediments being used as an end-member) and only $\approx 30 \%$ volcanic (Icelandic) particles. There is an exception (HL3): 

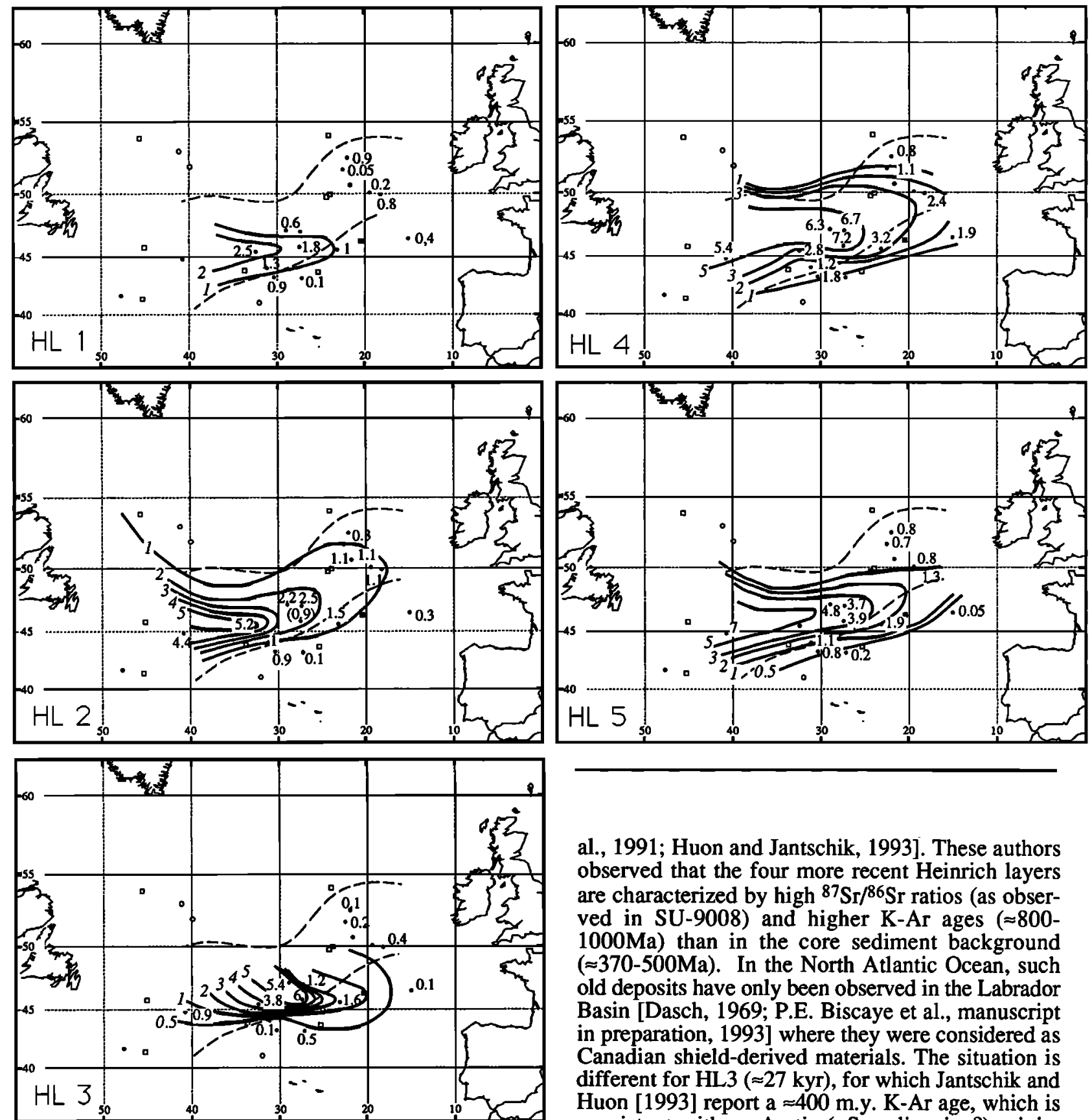

Fig. 7. Patterns of Heinrich layer: magnetic susceptibility integrated fluxes (expressed in $10^{-3}$ electromagnetic units $\mathrm{cm}^{-2} \mathrm{kyr}^{-1}$ ); HL1 to HL5; ice-rafted detritus belt [after Ruddiman, 1977] is shown in

this Heinrich layer has an isotopic composition very close to the values from the Fram Strait-Norwegian margin.

$\mathrm{K}-\mathrm{Ar}$ and $\mathrm{Rb}-\mathrm{Sr}$ isotopic compositions of the clay and silt fractions have been analyzed in core ME-6889 (same location as ME-69-17 in Figure 1)[Huon et

al., 1991; Huon and Jantschik, 1993]. These authors observed that the four more recent Heinrich layers are characterized by high ${ }^{87} \mathrm{Sr} /{ }^{86} \mathrm{Sr}$ ratios (as observed in SU-9008) and higher $\mathrm{K}-\mathrm{Ar}$ ages $(\approx 800-$ $1000 \mathrm{Ma})$ than in the core sediment background $(\approx 370-500 \mathrm{Ma})$. In the North Atlantic Ocean, such old deposits have only been observed in the Labrador Basin [Dasch, 1969; P.E. Biscaye et al., manuscript in preparation, 1993] where they were considered as Canadian shield-derived materials. The situation is different for HL3 $(\approx 27 \mathrm{kyr})$, for which Jantschik and Huon [1993] report a $\approx 400 \mathrm{~m}$.y. K-Ar age, which is consistent with an Arctic (+Scandinavian?) origin. Our observations confirm these results.

Mineralogical arguments are also consistent with this hypothesis. Bond et al. [1992] have observed that in all the HL from site 609, the mineralogy of the coarse ice-rafted grains was similar, with a strong component of detrital carbonate, except HL3. We have observed the same enrichment in detrital carbonate fragments for the uppermost Heinrich layers of cores SU-9008, SU-9011, and SU-9039 (Figure 1). Such layers rich in detrital carbonate also exist in core CH6909 [Pastouret et al., 1975] (Figure 1). The only englaciated regions in which large 


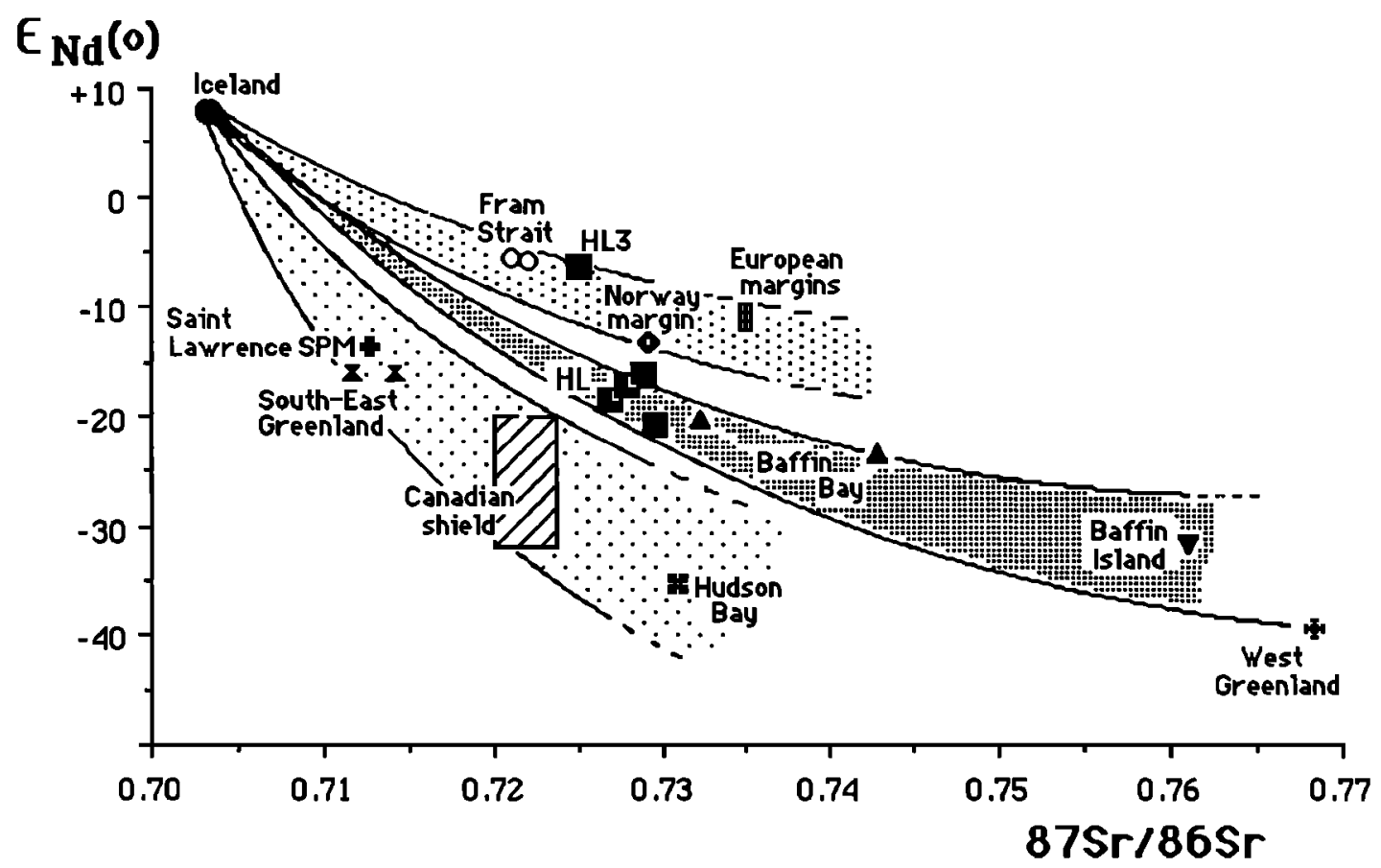

Fig. $8 .{ }^{87} \mathrm{Sr} /{ }^{86} \mathrm{Sr}$ ratios ploted against ${ }^{143} \mathrm{Nd} /{ }^{144} \mathrm{Nd}$ ratios. The ${ }^{143} \mathrm{Nd} /{ }^{144} \mathrm{Nd}$ ratios are expressed as $\epsilon_{\mathrm{Nd}}(0)=\left(\left(\left({ }^{143} \mathrm{Nd} /{ }^{144} \mathrm{Nd}\right)_{\text {meas }} / 0.512636\right)-1\right) * 10,000$. Analytical techniques have been previously described [Grousset et al., 1988; Grousset and Biscaye, 1989]. Error bars are smaller than symbol size. Nd and Sr isotopic data of the potential sources are from the literature: P.E. Biscaye et al. (unpublished manuscript, 1993), Faure et al. [1963], Goldstein and Jacobsen [1988a, b], Grousset et al. [1988], McCulloch and Wasserburg [1978], O'Nions and Pankhurst [1973], Stordal and Wasserburg [1986], Taylor et al. [1983], and Zindler et al. [1982]. On such a diagram, mixing lines are hyperbolae. Heinrich layer compositions (black squares) can be interpreted as a mixture of a mantle-derived end-member (Iceland+Greenland Volcanic Rocks (G.V.R.)) and a crust-derived end-member (Baffin Island+West Greenland regions for most of the HL, and Arctic+Norway for HL3).

deposits of limestone and dolomite are observed, are in eastern and northeastern regions [Latouche and Parra, 1979], Baffin Bay [Aksu and Piper, 1987] and Baffin Island [MacLean and Williams, 1983], although some smaller deposits exist in northern Europe and north-eastern Greenland (Figure 9).

\section{IMPLICATIONS FOR THE SURFACE CIRCU- LATION DURING THE LAST GLACIAL PERIOD}

Two models of circulation have been proposed to explain the distribution of ice-rafted material in the North Atlantic [Smythe et al., 1985]:

1. The first, the "locus-of-melting" model, links ice-rafted material accumulation to a stable southern boundary of the polar waters, where maximum melting of icebergs was occurring;

2. The second, the "ice-flow trajectories" model, considers a more progressive melting of icebergs flowing out of the ice-shelves, with accumulation of ice-rafted detritus along their trajectories.
Ruddiman [1977] argued that the ice-rafted detritus depositional patterns of the last glacial period, were consistent with the "locus-of-melting" model. The second model better explains the volcanic ash depositional patterns, probably transported by sea ice which melted faster [Ruddiman and Glover, 1975]. Each model appears to be relevant to different aspects of the Smythe et al. data [1985].

If we compare the maps of Figures 6 and 7, for HL2 (which occured near the Last Glacial Maximum) with the CLIMAP results [1976, 1981] and take into account further discussion of the hydrological implications from Keefer et al. [1988], then the accumulation of ice-rafted detritus follows approximately the northern limit of the zone of zero wind stress curl. This indicates a preferential accumulation and melting of the icebergs along the southern boundary of the polar waters. The western boundary of the high detrital fluxes zone would define the longitude of the injection from the north (the western limit of the associated cyclonic gyre). Most of the Heinrich layers have a Baffin Bay (and northwest 


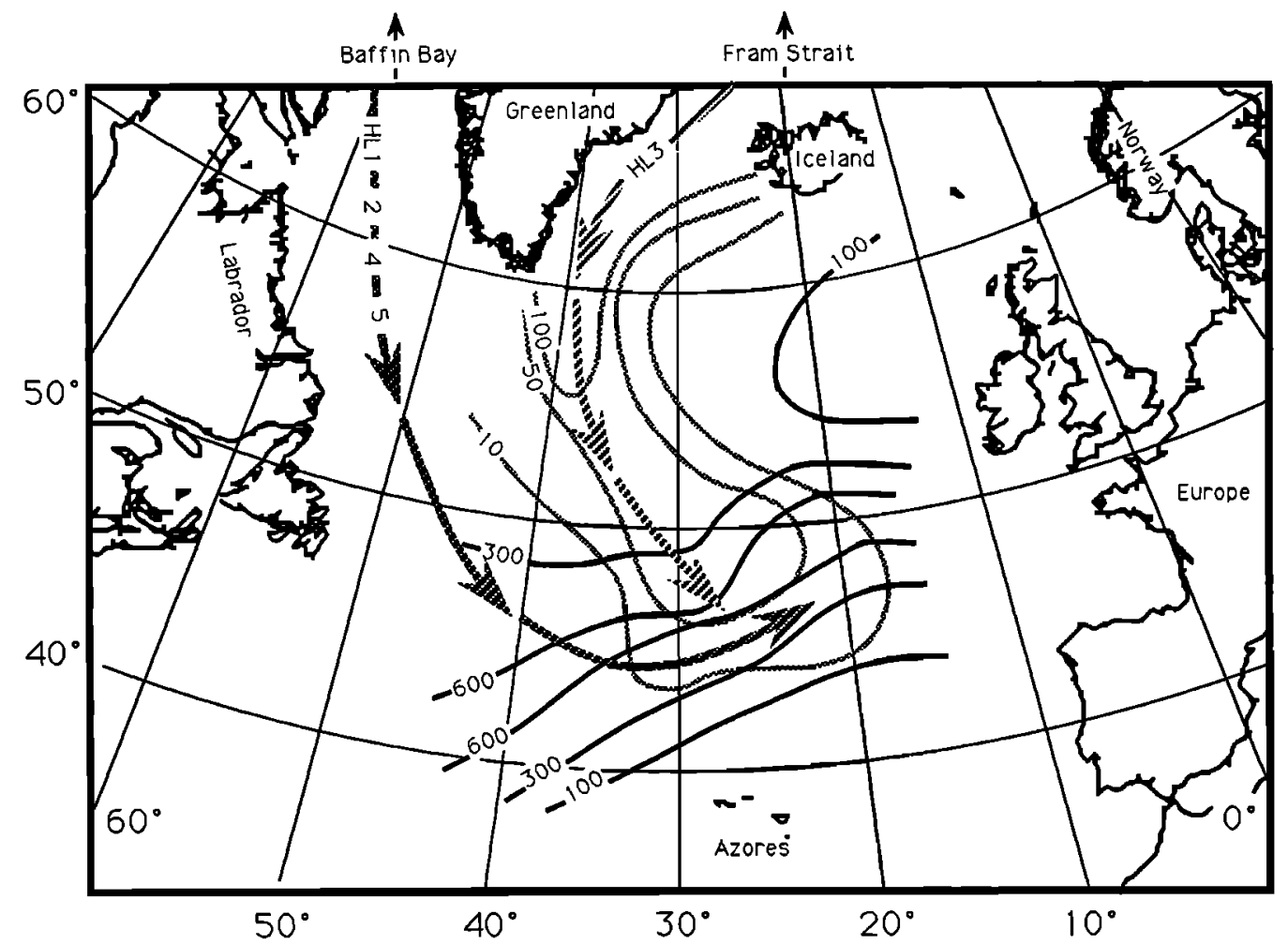

Fig. 9. Two different trajectory models can be proposed to reconcile HL patterns (Figures 6 and 7) and IRD source regions (Figure 8): during Heinrich events 1,2,4, and 5, icebergs were coming from the Baffin Bay, drifting across the Labrador Basin; during event 3, they were coming from the "Arctic" region, drifting across the Irminger Basin. These patterns fit the two trajectory models previously proposed by Smythe et al. [1985].

Greenland) origin (Figure 9). They do not have apparent contribution of detritus from the East Greenland province, and even from Scandinavian and/or the Arctic regions (Figure 8). HL3 in that scheme has not been injected in this northern cyclonic gyre of the western boundary (Figure 9), but more to the east (Arctic and/or Scandinavian regions), as revealed by its pattern (Figure 7), and its isotopic composition (Figure 8). Ruddiman and Glover [1972] have hypothesized a large cyclonic gyre within the Irminger Basin to explain the distribution of the volcanic material from ash zone 1 $(\approx 10.5 \mathrm{kyr} B P)$. The continuous "background" supply of volcanic materials (probably from the Icelandic area) throughout the last glacial period would support the permanence of such an "Irminger gyre," transporting sea-ice with local volcanic ashes. HL3 in such a case would represent an accidental injection of icebergs from the north and/or north east within this gyre. Cores located in the Irminger Basin might be studied to confirm this hypothesis.

However, another possibility can be discussed. The presence of detrital carbonate in HL3 in northern cores from the western North Atlantic is evidence that the pattern of circulation during HL3 in that region was about the same as during $\mathrm{HL} 1, \mathrm{HL} 2$,
HL4 and HL5 [see Bond et al., 1992]. In this view, icebergs that were discharged from the Labrador Sea during formation of HL3 melted, owing to warmer sea surface temperatures, before they reached the central and eastern North Atlantic. The different composition of IRD in HL3 may simply reflect the fact that if the massive discharges of icebergs from the Labrador Sea melt before crossing the western North Atlantic, the "Irminger gyre" becomes the principal source of icebergs reaching the central and eastern North Atlantic.

The southern boundary of the zone of high detritus flux, which appears slightly different from event-toevent (within a few degrees of latitude) would follow the north/south shifts of the southern margin of the polar waters along the last glacial period. In a recent paper, Hebbeln and Wefer [1991] reported ice-rafted detritus flux records measured over a year with sediment traps moored in the Fram Strait region. They clearly demonstrated that the maximum icerafted detritus fluxes occur where icebergs are melting, underneath the isotherm $\approx 0^{\circ} \mathrm{C}$, and that at the same time lithogenic fluxes are extremely low under the permanent sea ice and in the ice-free region. Although the time scales are different, such process could explain the HL distribution. 
In summary, while we may propose different hypotheses regarding the details of the circulation patterns [see Bond et al., 1992], we consider that the so-called "Heinrich layers" are likely a consequence of a huge iceberg input, mostly derived from the northern Labrador Basin margins (surges of Laurentide ice sheet, although this needs to be documented by more work on cores from the Labrador Basin?), followed by their southward transport by cyclonic surface circulation and their melting at the southern limit of the polar waters at about $45^{\circ} \mathrm{N}$, along the polar front. These events could be triggered by abrupt climatic coolings. We may propose a two-step scenario: when a Heinrich event starts, an immediate cooling of the surface waters would occurs (as indicated by the sharp increase in the $N$. pachyderma sin. absolute abundance occurring at the very beginning of the Heinrich events). The peak in N. pachyderma sin. observed in core SU-9008 just prior to each Heinrich event, implies a drastic southward penetration of polar waters, but also an increase in productivity (as recently proposed by Sancetta [1992]). This kind of increase has been described in present-day iceberg environments [Hebbeln and Wefer, 1991] and associated with a "ploughing" of nutrient-rich surface waters [Neshiba, 1977] may be as deep as $\approx 1000 \mathrm{~m}$. Then, the invasion and subsequent melting of icebergs would induce a strong input of IRD, and the surface waters would be cold enough to explain that only some foraminifera survived, as indicated by the sharp increase in the $N$. pachyderma sin. relative abundance associated to the IRD peak. North of the IRD belt, there was no significant melting of icebergs and, thus the IRD flux was negligible except along the coastal zones concerned by sea ice transport. The southern limit of the IRD belt marks the maximum southward penetration of polar water and associated icebergs.

Similar IRD events can be identified at least since $260 \mathrm{ky}$ (see on Figure 3) and will have to be studied in future work.

In the Greenland ice cores, Johnsen et al. [1992] observe several rapid warming events which interrupt the cold periods (low $\delta^{18} 0$ ). These cold periods appear to correspond approximately in timing to the North Atlantic Heinrich events. But, with the very brief warm periods superimposed, their structure is much more complex than those of the sedimentary records. The resolution of the sediment analysis must be increased in order to ascertain the more detailed relationship. If such brief events can be demonstrated in the sediments, that would indicate an even faster evolution of the ice margins.

\section{FURTHER CONSIDERATION ON HEINRICH EVENTS NUMBERING}

The magnetic susceptibility measurements rapidly yield a continuous signal that is convenient to establish stratigraphy and to define the major glacial cycles boundaries in complement to the grey scale analysis. It is crucial therefore to decipher the longterm structure and variability of the signal. A convenient denomination for each of the events becomes mandatory, as proved by the experience of the $\delta^{18} \mathrm{O}$ isotopic and sapropel stratigraphies.

The system introduced by Heinrich, which increments the number at each observed event in his cores, with jumps at levels which may (?) exist, is simple but yields already to considerable incoherencies. From place to place, some events may have a major or minor imprint, and in the latter case be easily overlooked. HL3 is typical of the latter case because it is not apparent in the western cores. To limit the uncertainty factor (by not propagating errors), we propose to derive the denomination of the events from the well-calibrated $\delta^{18} \mathrm{O}$ isotopic scale, using as first digit an incrementation of the Heinrich events limited to the events within a stage following the isotopic stage number (as Martinson et al. [1987] defined isotopic substages). For example the third HL in isotopic stage 6 ( $\approx 165 \mathrm{kyr}$ B.P.) will be HL63. Within that scale HL1 to HL6 would become HL2-1, HL2-2, HL3-1, HL3-2, HL3-3, and HL4-1.

\section{CONCLUSIONS}

The short events of ice-rafted detritus accumulation during the last glacial, identified by Heinrich [1988] in the Northeast Atlantic and recently documented at high resolution by Broecker et al. [1992], are not a local pattern, but occur roughly between $40^{\circ} \mathrm{N}$ and $55^{\circ} \mathrm{N}$ across the entire North Atlantic. Considering the patterns of the so-called "Heinrich layers", the origin of the lithic grains, and their cyclic occurrence, we may propose an overall interpretation. Most of the Heinrich events could be a consequence of three, interacting mechanisms: (1) a massive input of icebergs derived from the northern Labrador Basin margins; (2) southward transport along the western boundary by cyclonic surface circulation; (3) melting at the southern limit of the polar waters at about $45^{\circ} \mathrm{N}$, along the polar front. This situation apparently occurred roughly every 12 kyr. Some other events (like HL3), which originated in eastern Greenland, or in the Norwegian ice sheets, joined the main westerly drift after westward then southward transport along the path of a central northern Atlantic cyclonic gyre. We have identified these events at least since $\approx 260 \mathrm{kyr}$. They appear to be triggered by, or at least associated with, strong climatic coolings, as indicated by the sharp increase in the $N$. pachyderma sinistrial relative abundance occurring during the HL events. However, HL events are not particularly associated with maximum volumes of the ice sheets, as they occurred during interstadial stage 3 , as well as during the last glacial maximum and isotopic stage 4.

Acknowledgments. J. Poutiers (D.G.O., University Bordeaux I, deceased in 1987), was the initiator 
of the study of low-field magnetic susceptibility of oceanic sediments in France: he analyzed the Faegas III cores reported here. For the Paleocinat SU-90 cores, magnetic susceptibility was measured onboard with a device developped at CFR (Gif-sur-Yvette) by François Guichard and René Manganne. Noëlle Maillet (D.G.O., University Bordeaux I) ran X ray mineral analyses. B. Lecoat, J. Tessier, and J. Antignac are in charge of the running of the Finnigan Mat 251 and the automated carbonate device (individual and bulk) for the foraminiferal isotopic analyses in Gif-sur-Yvette. We acknowledge their contribution to this study. We are very grateful to E. Jansen (University of Bergen), who provided Norwegian margin sediment samples (Core 25-09), and D. Hebbeln (University of Bremen), who gave us sediment trap samples from the Fram Strait. We thank M. Loubet for access to the mass spectrometer Finnigan Mat 261 at the Laboratoire de Géochimie Isotopique (Toulouse). We thank P.E. Biscaye for friendly and helpful comments on a first draft of the manuscript. The paper benefitted greatly by thoughtful reviews by Jean-Claude Duplessy, John King, Eystein Jansen, William Ruddiman, Hartmut Heinrich and Rüdiger Jantschik. This research was directly supported by the INSU-CNRS program: "Dynamique et Bilan de la Terre-Thème 2," EEC program EPOCH, and the basic support of CNRS and CEA to CFR, and CNRS and MEN to DGO. This is DBT-2 contribution 534, CFR contribution 1338A, L-DEO contribution 5039.

\section{REFERENCES}

Aksu, A. E. and D. J. W. Piper, Late quaternary sedimentation in Baffin Bay, Can. J. Earth Sci., 24, 1833-1846, 1987.

Bard, E., M. Arnold, P. Maurice, J. Duprat, J. Moyes, and J.-C. Duplessy, Retreat velocity of the North Atlantic polar front during the last deglaciation determined by ${ }^{14} \mathrm{C}$ accelerator mass spectrometry, Nature, 326, 1987.

Bond, G., M.A. Kominz, W.S. Broecker, M. Klas, and J. McManus. Do color variations in North Atlantic deep-sea cores record Holocene-Pleistocene climatic changes in Milankovitch and sub-Milankovitch scales? Geol. Soc. Am., Abstr. Programs, A 78, 1990.

Bond, G., W.S. Broecker, M. Klas, R. Lotti, and J. McManus, Abrupt color change in isotopic stage 5 in North Atlantic deep-sea cores: Implications for rapid change of climate-driven events, edited by G. Kukla and E. Went, NATO ASI, Ser. 1, 3, 185-206, 1991.

Bond, G., H. Heinrich, S. Huon, W. Broecker, L. Labeyrie, J. Andrews, J. McManus, S. Clasen, K. Tedesco, R. Jantschik, C. Simet, and M. Klas, Evidence for massive discharges of icebergs into the glacial Northern Atlantic, Nature, 360, 245$249,1992$.

Broecker, W., G. Bond, and M. Klas, A salt oscilla- tor in the Glacial Atlantic? 1, The Concept, Palaeoceanography, 5 (4), 469-477, 1990.

Broecker, W., G. Bond, M. Klas, E. Clark, and J. McManus, Origin of the Northern Atlantic's Heinrich events, Clim. Dyn., 6, 91-109, 1992.

CLIMAP, The surface of the ice-age Earth, Science, 191, 1131-1137, 1976.

CLIMAP, Seasonal reconstruction of the Earth's surface at the last glacial maximum, Geol. Soc. Am. Map Chart Ser., MC36, 1981.

Dasch, E.J., Strontium isotopes in weathering profiles, deep-sea sediments and sedimentary rocks Geochim. Cosmochim. Acta, 33, 1521-1552, 1969.

Duplessy, J.C., L. Labeyrie, A. Juillet-Leclerc, F. Maitre, J. Duprat, and M. Sarnthein, Surface salinity reconstruction of the north Atlantic ocean during the last glacial maximum, Oceanol. Acta, 14, 311-324, 1991.

Faure, G., P.M. Hurley, and H.W. Fairbairn, An estimate of the isotopic composition of strontium in rocks of the precambrian shield of North America. J. Geophys. Res., 68, 2323-2329, 1963.

Faure, G., Principles of Isotope Geology, 2nd ed., 589pp., John Wiley, New York, 1986.

Goldstein, S.J., and S.B. Jacobsen, $\mathrm{Nd}$ and $\mathrm{Sr}$ isotopic systematics of river water suspended material: Implications for crustal evolution, Earth Planet. Sci. Lett., 87, 249-265, 1988a.

Goldstein, S.J., and S.B. Jacobsen, REE in the Great Whale River estuary, northwest Quebec, Earth Planet. Sci. Lett., 88, 241-252, 1988 b.

Grousset, F.E., and P.E. Biscaye, $\mathrm{Nd}$ and $\mathrm{Sr}$ isotopes as tracers of wind transport in Atlantic aerosols and surface sediments, edited by $\mathbf{M}$. Leinen and M. Sarnthein, NATO ASI Ser. 282(C), 385-400, 1989.

Grousset, F.E., and R. Chesselet, Holocene sedimentary regime on the North Mid-Atlantic Ridge, Earth Planet. Sci. Lett., 78, 271-287, 1986.

Grousset, F.E., J. Duprat J., Faugères, E. Gonthier, N. Maillet, J. Poutiers, and A. Pujos-Lamy, Un domaine sédimentaire de dorsale océanique (43-56²N.). Résultats de la mission Faegas-3, Bull. Institut de Géologie du Bassin d'Aquitaine, $\underline{28}, 43-83,1981$.

Grousset, F.E., P.E. Biscaye, A. Zindler, J. Prospero, and R. Chester, Neodymium isotopes as tracers in marine sediments and aerosols: North Atlantic. Earth Planet. Sci. Lett., 87, 367-378, 1988.

Hammer, C.U., Traces of Icelandic eruptions in the Greenland ice sheet, Jokull, 34, 51-65, 1984.

Hebbeln, D., and G. Wefer, Effects of ice coverage and ice-rafted material on sedimentation in the Fram Strait, Nature, 350, 409-411, 1991.

Heinrich, H., Origin and consequences of cyclic icerafting in the northeast Atlantic Ocean, during the past 130,000 yrs, Quat. Res., 29, 143-152, 1988.

Huon, S., R. Jantschik, B. Kubler, and D. Fontignie, Analyses K-Ar, Rb-Sr et minéralogiques des 
fractions argileuses de sédiments quaternaires, Atlantique NE: Résultats préliminaires, Schweiz. Mineral. Petrogr. Mitt., 71, 275-280, 1991.

Huon, S., and R. Jantschik, Detrital silicates in Northeast Atlantic deep-sea sediments during the Late Quaternary, 2, Major elements, REE and RbSr isotopic data, Eclo. Geol. Helv., 86(1), 1993.

Jantschik, R., and S. Huon, Detrital silicates in Northeast Atlantic deep-sea sediments during the Late Quaternary, 1, Mineralogical and $\mathrm{K}$-Ar isotopic data, Eclo. Geol. Helv., $\underline{85}$ (1), 195-212, 1992.

Johnsen, S., N.B. Clausen, W. Dansgaard, K. Fuhrer, N. Gundesdrup, C.U. Hammer, P. Ivevsen, J. Jouzel, B. Stauffer, and J.P. Steffensen, Irregular glacial Interstadials recorded in a new Greenland ice-core, Nature, 359,311-313, 1992.

Keefer, T., D.G. Martinson, and B.H. Corliss, The position of the Gulf Stream during Quaternary glaciations, Science, 241, 440-442, 1988.

Latouche, C., and M. Parra, La sédimentation au Quaternaire récent, dans le Northwest Atlantic Mid-Ocean Canyon. Données minéralogiques et géochimiques, Mar. Geol., 29, 137-164, 1979.

MacLean, B., and G.L. Williams, Geological investigations of Baffin Island shelf in 1982, Geol. Surv. Can., 83(1B), 309-315, 1983.

Martinson, D.G., N.G. Pisias, J.D. Hays, J. Imbrie, T.C. Moore, and N.J. Shackleton, Age dating and the orbital theory of the ice ages: Development of a high resolution 0-300,000-year chronostratigraphy, Ouat. Res., 27, 1-29, 1987.

McCulloch, M.T., and G.J. Wasserburg, Sm-Nd and $\mathrm{Rb}-\mathrm{Sr}$ chronology of continental crust formation, Science, 200, 1003-1011, 1978.

Neshiba, S., Upwelling by icebergs, Nature, 267, 507-508, 1977.

O'Nions, R.K., and R.J. Pankhurst, Secular variation in the Sr-isotope composition of Icelandic volcanic rocks, Earth Planet. Sci. Lett., 21, 1321, 1973.

Pastouret, L., G. Auffret, M. Hoffert, M. Melguen, H.D. Needham, and C. Latouche, Sédimentation sur la ride de Terre-Neuve, Can. J. Earth Sci., 12, 1019-1035, 1975.

Poutiers, J., Sur les propriétés magnétiques de certains sédiments continentaux et marins: applications, thèse de doctorat, 492, 266pp., Univ. Bordeaux I, 1975.

Poutiers, J., and E. Gonthier, Sur la susceptibilité magnétique des sédiments, indicateur de la dispersion du matériel volcanoclastique à partir de l'Islan-de et des Faeroë, Bull. Institut de Géologie du Bassin d'Aquitaine, 23, 214-226, 1978.
Robinson, S.G., The late Pleistocene paleoclimatic record of north Atlantic deep-sea sediments revealed by mineral-magnetic measurements, Phys. Earth Planet. Int., 42, 22-47, 1986.

Ruddiman, W.F. Late Quaternary deposition of icerafted sand in the subpolar North Atlantic (lat $40^{\circ}$ to $65^{\circ} \mathrm{N}$ ), Geol. Soc. Am. Bull., $\underline{88}, 1813-1827$, 1977.

Ruddiman, W.F., and L.K. Glover, Vertical mixing of ice-rafted volcanic ash in North-Atlantic sediments, Geol. Soc. Am. Bull., 83, 2817-2836, 1972.

Ruddiman, W.F. and L.K. Glover, Subpolar northAtlantic circulation at 9,300 yr B.P.: Faunal evidence, Ouat. Res., $\underline{5}, 361-389,1975$.

Sancetta, C. Primary production in the Glacial North Atlantic and North Pacific oceans, Nature, $\underline{360}$, 249-251, 1992.

Shaw, D.M., J. Dostal, and R.R. Keays, Additional estimates of continental surface precambrian shield. Can. J. Earth Sci., 40(1), 73-83, 1976.

Smythe, F.W., Jr., W.F. Ruddiman, and D.N. Lumsden, Ice-rafted evidence of long-term NorthAtlantic circulation, Mar. Geol., 64, 131-141, 1985.

Stordal, M.C., and G.J. Wasserburg, Neodymium isotopic study of Baffin Bay water: Sources of REE from very old terranes, Earth Planet. Sci. Lett., 77, 259-272, 1986.

Taylor, S.R., S.M. McLennan, and M.T. McCulloch, Geochemistry of loess, continental crustal composition and crustal model ages, Geochim. Cosmochim. Acta, 47, 1897-1905, 1983.

Zindler, A., E. Jagoutz, and S.L. Goldstein, Nd, Sr and $\mathrm{Pb}$ systematics in a three component mantle, Nature, 298, 519-523, 1982.

G. Bond, Lamont-Doherty Earth Observatory, Columbia University, Palisades, NY 10964.

E. Cortijo and L. Labeyrie, Centre des Faibles Radioactivités, Avenue de la Terrasse, 91198 Gifsur-Yvette, France.

M. Cremer , J. Duprat , F. E. Grousset, and J.-A. Sinko, Département Géologie et Océanographie, URA CNRS 197, Université Bordeaux I, Avenue des Facultés, 33405 Talence Cedex, France.

S. Huon, Département de Minéralogie, 13 rue des Maraîchers, CH-1211 Genève 4, Switzerland.

(Received July 30, 1992;

revised December 7, 1992;

accepted December 10, 1992.) 